\title{
Innovative Therapeutic Approaches for Improving Patient Life Condition with a Neurological Lysosomal Disease
}

\author{
Audrey Arfi, Magali Richard and Daniel Scherman \\ CNRS, Inserm, Université Paris Descartes, Sorbonne Paris Cité, Faculté de Pharmacie, \\ Chemical and Genetic Pharmacology Laboratory, Paris, \\ Ecole Nationale Supérieure de Chimie de Paris, Chimie ParisTech, Paris,
}

France

\section{Introduction}

\subsection{Introduction on Lysosomal Storage Diseases (LSDs): Focus on several neuronopathic LSDs}

Lysosomal storage diseases (LSD) are monogenic inherited metabolic disorders, most of which are caused by the deficiency of a lysosomal enzyme. The deficient proteins may be hydrolases or cofactors involved in the degradation of macromolecules or transporters, which deliver catabolic products to the cytosol. Most of lysosomal enzymes are exohydrolases acting in sequence, such that substrates are degraded by a stepwise removal of terminal residues. Thus, the deficiency of a single enzyme causes the blockage of the entire pathway, since the failure to remove a terminal residue makes the substrate inaccessible for further hydrolysis by other lysosomal enzymes. The lysosomal storage diseases can be classified depending on the pathway affected and the nature of the accumulated substrate. Eleven different deficiencies can affect the degradation of mucopolysaccharides (mucopolysaccharidoses), nine defects are known in the degradation pathways of glycoproteins, one for the intralysosomal storage of glycogen (glycogenesis), twelve different ceroid lipofuscinoses are known, and twelve deficiencies affect sphingolipid catabolism (lipidoses). However, there are frequent overlaps of storage material between those groups. Many lysosomal hydrolases are not specific for a particular compound, but rather for a terminal residue, which may be identical in, e.g., gangliosides and glycoproteins, so that both compounds accumulate when a commonly required enzyme is deficient.

Almost all lysosomal storage diseases show clinical variability. Most diseases vary with respect to the age at onset and progression of the symptoms. The later a disease begins the more protracted is the development of symptoms. Frequently, three different types of disease are distinguished, severe infantile, intermediate juvenile and mild adult forms, respectively. Although such a classification is useful, it should be realized that the spectrum of clinical severity is a continuum, and such imposed distinctions are artificial. In many lysosomal disorders symptoms, the early and late onset forms are similar, but in some 
diseases, defects in the same gene may cause very different phenotypes. For example, betao-galactosidase deficiency can cause either GM1 gangliosidosis or Morquio type B disease. Whereas in GM1 gangliosidosis neurologic degeneration is the major symptom, patients with Morquio Type B disease have no neurologic involvement, but display severe skeletal dysplasias. Similarly, several Gaucher disease forms (neuropathic - also called neuronopathic - and non neuronopathic) are distinguished depending if there is impairment of the central nervous system. This chapter will focus on some LSDs with neurological involvement, including several lipidoses and mucopolysaccharidoses. Other neuronopathic LSDs exist, such as the Ceroid Lipofuscinoses family, but will not be presented in this chapter.

\subsection{Lipidoses with neurological involvement: Biochemistry, clinical features and genetics}

\subsubsection{GM1 gangliosidoses}

Deficiency of the enzyme beta-D-galactosidase can cause very different clinical phenotypes, beta-o-galactosidase hydrolyses beta-glycosidically linked terminal galactose residues from a variety of different substrates. These substrates are lipids such as GM1 ganglioside (Norden et al., 1974), oligosaccharides with terminal galactose (O'Brien, 1989; Ying and Wolfe, 1975) or galactose containing intermediates of the degradation of the mucopolysaccharide keratan sulfate (O'Brien, 1989; Tsay and Dawson, 1973). A complete deficiency of the enzyme results in the storage of all substrates [O'Brien, 1989; Ying and Wolfe, 1975; Tsay and Dawson, 1973). Accordingly, GM1 gangliosidosis presents clinical neurologic symptoms, which can be attributed to the storage of GM1 ganglioside in neurons, while storage of keratan sulfate catabolic intermediates in the viscera results in hepatosplenomegaly and severe bone deformities typical for mucopolysaccharidoses. The GM1 gangliosidosis may occur as a severe rapidly progressing infantile disease in which the neurologic symptoms dominate the clinical picture, but skeletal deformities, edema, hepatomegaly and coarse facial features are also present (O'Brien, 1989). The adult form of GM1 gangliosidosis shows mild, slowly progressing neurologic involvement like dysarthrias or gait disturbances and, except for vertebral dysplasias, little involvement of the skeleton (O'Brien, 1989). The beta-D-galactosidase cDNA (Oshima et al., 1988) and the gene (Morreau et al., 1991) have been cloned and a variety of mutations have been characterized. Defective alleles are heterogeneous and no single mutation with a particular high frequency has been found.

\subsubsection{GM2 gangliosidoses}

This group of diseases is characterized by storage of GM2 ganglioside (Sandhoff et al., 1989). Three polypeptide chains encoded by three different genes are involved in the degradation of GM2 ganglioside. The synthesis of an alpha and beta subunit for hexosaminidase (beta-Nacetyl-D-hexosaminidase) allows for the formation of three isoenzymes alpha-alpha, alphabeta, beta-beta, which are designated hexosaminidase S, A, and B (Sandhoff et al., 1989). In order to be hydrolysed by hexosaminidase $\mathrm{A}$, the ganglioside has to be associated with a third polypeptide, the GM2 activator protein, which solubilises the substrate for the action of the enzyme (Meier et al., 1991; Conzelmann and Sandhoff, 1979). The storage of GM2 ganglioside can therefore be due to mutations in three different genes: (1) the 
hexosaminidase alpha-subunit gene, which causes classical Tay Sachs disease or late onset GM2 gangliosidosis (variant B); (2) the beta-subunit gene, which causes early or late onset Sandhoff disease (variant 0); and (3) the GM2 activator protein (variant AB) (Sandhoff et al., 1989). These variant forms of disease are clinically similar, but differ in the composition of compounds which, in addition to GM2 gangliosides, are also found in the storage material. The presence of additional compounds is due to the fact that GM2 ganglioside is not the only substrate of hexosaminidase $\mathrm{A}$, and that the isoenzymes differ in their substrate specificities and dependence on the presence of the GM2 activator protein. Since all variant forms of disease are similar, the symptoms seem to be mainly due to the storage of GM2 ganglioside and not that of other compounds.

Classical Tay Sachs disease is characterized by a rapidly progressing neurological degeneration. The disease starts in between 3 to 5 months of age with progressive weakness and hyperirritability. A macular cherry red spot is seen in all Tay Sachs patients. Progression of neurologic symptoms leads to the decerebrate, vegetative state in the second to fourth year of life (Sandhoff et al., 1989). In the juvenile form, disease onset occurs later and disease progression is slower. Adult GM2 gangliosidosis represents the mildest form of the disease, displaying neurologic symptoms of spinocerebellar and lower motor neuron origin, like ataxias, dysarthrias and muscle weakness. Psychiatric symptoms are frequently present. A particular variant, which has been termed chronic, starts in between the age of 2 and 5, but patients survive well into adulthood (Sandhoff et al., 1989).

Tay Sachs disease is most prevalent in the Ashkenazi Jewish population. Three defective hexosaminidase alpha subunit alleles account for $93 \%$ of all mutant alleles in this ethnic group (Paw et al., 1990). Two other ethnic groups, both descendants from French settlers, have a high incidence of Tay Sachs disease. One is the Cajun community in southwest Louisiana, in whom the $4 \mathrm{bp}$ insertion in exon 11 was found in 11 of 12 mutant alleles examined (McDowell et al., 1992). The other group concerns French Canadians, in which a $7.6 \mathrm{~kb}$ deletion in the 5 ' region of the gene, which has occurred by illegitimate recombination between Alu repeats, accounts for more than $80 \%$ of defective alleles (Myerowitz and Hogikyan, 1987; Hechtman et al., 1990). Enzyme deficiencies, which do not cause disease, have been termed pseudodeficiencies. Pseudodeficiencies are without clinical consequences for the carriers, but cause problems in the diagnosis and genetic counselling.

In Sandhoff disease, the beta-subunit deficiency causes the loss of isoenzymes A and B. The clinical phenotype and heterogeneity is similar to that found in Tay Sachs disease. The cDNA (O'Dowd et al., 1985) and the gene of the beta-subunit of hexosaminidase have been cloned (Proia, 1988; Neote et al., 1988). The disease is rare, but there are some demographic isolates with a high frequency, e.g. in a region around the town of Cordoba in Argentina (Brown et al., 1992). The most frequent defect found in the beta chain gene is a $16 \mathrm{~kb}$ deletion that removes the promoter and exons 1 to 5 . Homozygosity of the allele causes the severe late infantile form of the disease (Neote et al., 1990). As in Tay Sachs disease the milder forms have been found to be associated with mutations leading to the synthesis of enzymes displaying some residual activity (Bolhuis et al., 1993).

The third polypeptide involved in the degradation of GM2 ganglioside is the GM2 activator protein. The deficiency of this protein is rare and causes a disease that is clinically similar to Tay Sachs disease. This small $24 \mathrm{kDa}$ protein interacts with the alpha-subunit of the hexosaminidase isoenzyme A (Kytzia and Sandhoff, 1985) and solubilizes lipids such as 
GM2 ganglioside or GA2 glycolipid for the hydrolysis by hexosaminidase A (Conzelmann and Sandhoff, 1979). The cDNA and gene of this protein have been cloned (Klima et al., 1991), and five mutations have been described so far.

\subsubsection{Niemann Pick disease}

Niemann Pick disease type A and B are caused by a deficiency of the enzyme acid sphingomyelinase (Spence and Callahan, 1989). This enzyme hydrolyses sphingomyelin into ceramide and phosphorylcholine. Deficiency of the lysosomal enzyme causes storage of sphingomyelin (Spence and Callahan, 1989). Two types of disease can be distinguished an acute type A and a chronic type B disease. The acute form is a severe disorder of infancy characterized by progressive psychomoter retardation, massive visceromegaly and death by 3 years of age. The chronic form is characterized by a visceromegaly, but little involvement of the nervous system and survival into adulthood. Accordingly, the two types of disease are termed neuronopathic (type A) and nonneuronopathic (type B). The disease is panethnic, but has a higher frequency among Ashkenazi Jews. The cDNA (Quintern et al., 1991) and the gene (Schuchman et al., 1992) of sphingomyelinase have been cloned. Three mutant alleles have been found to be most frequent among Ashkenazi Jews.

In addition to Niemann Pick type A and B there is a third clinically similar form termed type C. Cells from these patients show an impaired intracellular transport of cholesterol from lysosomes, but the primary defect is not in the sphingomyelinase gene and has so far not been elucidated.

\subsubsection{Metachromatic leukodystrophy}

The deficiency of arylsulfatase A causes metachromatic leukodystrophy. The substrate of this enzyme is cerebroside-3-sulfate (sulfatide). This glycolipid is mainly found in the myelin sheaths of the nervous system. Deficiency of arylsulfatase A causes storage of sulfatide in various organs, but the disease mainly affects the nervous system (Kolodny, 1989). Patients suffer from progressive demyelination, which leads to a variety of neurologic symptoms and finally causes death. Typically the disease starts with gait disturbances at the age of 18 to 24 months, in the further course of disease patients develop a spastic tetraparesis, seizures and dementia. In the milder late onset forms psychiatric symptoms frequently prevail initially before neurologic symptoms become apparent (Kolodny, 1989). Arylsulfatase A is encoded in a small gene (Kreysing et al., 1990), and the entire coding sequence of $1.5 \mathrm{~kb}$ is distributed over 8 exons and encompasses not more than $3 \mathrm{~kb}$ of genomic sequence. Two mutant alleles are particularly frequent and account each for about 25\% of mutant alleles among Caucasian patients (Polten et al., 1991; Barth et al., 1993). Deficiency of arylsulfatase A has also been demonstrated in healthy individuals at high frequency (up to $2.6 \%$ of the population) (Barth et al., 1993; Hohenschutz et al., 1989). The deficiency is substantial, but since it is not complete it does not cause a disease and is another example of lysosomal enzyme pseudodeficiency (Dubois et al., 1977).

\subsubsection{Gaucher disease (neuronopathic)}

Gaucher disease is caused by the deficiency of beta-0-glucocerebrosidase (Brady et al., 1965). The enzyme hydrolyses glucose from the sphingolipid glucosylceramide (Brady et al., 1965). 
Glucosylceramide is an intermediate compound in the synthesis and degradation of complex glycosphingolipids. Deficiency of the enzyme causes storage of glucosylceramide mainly in cells of the monocyte/macrophage system (Grabowski, 1993). Generally, Gaucher disease affects the bone marrow, bone, spleen, and liver, causing anaemia, thrombocytopenia, bone lesions and hepatosplenomegaly. In the less frequent, more severe forms of the disease, the central nervous system is also affected and, as in Niemann Pick disease, these variants have been termed neuronopathic.

The severe neuronopathic form (type II Gaucher disease) is rare and occurs panethnically, i.e. without any ethnic distinction. It presents hepatosplenomegaly and neuronal complications (Grabowski, 1993). The clinical presentation is quite uniform and death usually occurs before 2 years of age.

The mild nonneuronopathic form (type I disease) is frequent among Ashkenazi Jews and is clinically heterogeneous. A third intermediate form of Gaucher disease (type III) is a so called "subacute neuronopathic form", which, due to its high frequency in a Swedish isolate, has also been termed Norbottnian type Gaucher disease (Dahl et al., 1990). Patients show neuronal as well as visceral involvement, but the neurological symptoms develop later and more slowly than in the acute neuronopathic form.

The cDNA, the gene and pseudogene of beta-D-glucocerebrosidase have been cloned (Sorge et al., 1985; Horowitz et al., 1989). The pseudogene is tightly linked to the normal gene, but is smaller due to several mainly intronic deletions. At least 200 different mutations have been characterized (Pastores et al., 2000). Most of these mutations are rare and some are limited to single families. However, five of the mutant alleles account for more than $98 \%$ of defective beta-D-glucocerebrosidase alleles among Ashkenazi and for about $70 \%$ of mutant alleles among non Jews (Beutler, 1993; Horowitz et al., 1993).

\subsubsection{Krabbe disease}

Krabbe disease or globoid cell leukodystrophy is due to the deficiency of beta-Dgalactocerebrosidase (Suzuki and Suzuki, 1989). The enzyme releases galactose from galactocerebroside, one of the major membrane lipids of the myelin sheaths. Like in metachromatic leukodystrophy patients suffer exclusively from neurologic symptoms (Suzuki and Suzuki, 1989). In the first six months of life, they display hyperirritability towards external stimuli, hyperaesthesia, spasticity and regression of neurologic development. Patients usually die before their second year of life in a decerebrate state (Suzuki and Suzuki, 1989). In addition late onset forms have been described. The cloning of the gene has been difficult due to the low abundance and hydrophobicity of the enzyme, but has recently been achieved (Chen et al., 1996; Sakai, 1994). The purified enzyme has a molecular weight of $51 \mathrm{kDa}$. The cloned cDNA has 3795 nucleotides, of which 2007 nucleotides represent an open reading frame, predicting a 669 amino acids protein (Chen et al., 1996). Although the substrates of beta-D-glucocerebrosidase and beta-Dgalactocerebrosidase are structurally similar, no sequence homology between the two enzymes has been found. A nonsense mutation was found at codon 369 (GAA > TAA) in the coding sequence of cDNA amplified from cultured skin fibroblast mRNA from a patient with typical Krabbe disease (Sakai, 1994). 


\subsection{Mucopolysaccharidoses with neurological involvement: Biochemistry, clinical features and genetics}

Mucopolysaccharidoses (MPS) are a subgroup of lysosomal storage diseases caused by a deficiency in specific acid hydrolases responsible for the degradation of complex glycosaminoglycans (GAGs) (Neufeld and Muenzer, 2001), which causes substrate accumulation within the lysosomes of the cells of the central nervous system (CNS) and of other organs. As already stated, only the MPS which display neurological traits will be described here. This concerns MPS types I, II, III and VII. Patients with neurologic MPS share several clinical signs, including a severe neurodeterioration and systemic symptoms.

\subsubsection{Mucopolysaccharidosis type I}

Mucopolysaccharidosis type I (MPS I) is caused by the deficiency of alpha-L-iduronidase. This enzyme cleaves terminal iduronic acid residues from the glycosaminoglycans heparan and dermatan sulfate (Neufeld and Muenzer, 2001). Deficiency causes storage and urinary excretion of undegraded or partially degraded heparan and dermatan sulfate mucopolysaccharides (Neufeld and Muenzer, 2001). The spectrum of clinical phenotypes is broad. In the severe form, patients typically show symptoms in the first year of life presenting with hepatosplenomegaly, skeletal dysplasias, corneal clouding, short stature and mental retardation. These severe forms have been termed Hurler syndrome. At the other end of the clinical spectrum are the patients with mild form of disease termed Scheie syndrome. They have little or no neurologic involvement, have mild hepatosplenomegaly, joint stiffness and deformities, heart valve problems, but may have a normal lifespan. Intermediate phenotypes have accordingly been termed Hurler/Scheie syndrome (Neufeld and Muenzer, 2001).

The cDNA and the gene of the a-L-iduronidase have been cloned (Scott et al., 1991; Scott et al., 1992). The emerging pattern of genotype-phenotype correlation in MPS I ressembles that of other lysosomal storage diseases, in so that homozygosity for null alleles causes severe disease and alleles associated with some residual activity allow for a milder course of the disease.

\subsubsection{Mucopolysaccharidosis type II}

Mucopolysaccharidosis type II (MPS II) is caused by the deficiency of alpha-L-iduronate-2sulfate sulfatase. The enzyme desulfates iduronate-2-sulfate residues, which can be found in heparan and dermatan sulfate. Deficiency of the enzyme causes accumulation of degradation intermediates (Neufeld and Muenzer, 2001). MPS II is the only mucopolysaccharidosis that is inherited as an X linked trait. Clinically, it resembles MPS I, with skeletal abnormalities, hepatosplenomegaly, but less severe mental retardation and no corneal clouding. The spectrum of clinical severity is broad, alpha-L-iduronate- 2-sulfate sulfatase cDNA has been cloned and the structure of the gene has been determined (Wilson et al., 1990; Wilson et al., 1993). The cDNA sequence predicts a protein of 550 amino acids and the deduced amino acid sequence shows a strong homology to other lysosomal and non lysosomal sulfatases. The gene seems to be prone to deletions, which have been detected in about every fourth patient (Wilson et al., 1991; Palmieri et al., 1992). Complete deletions of the gene can be found in $8 \%$ of patients (Bunge et al., 1992), and those always suffer from the 
most severe type of MPS II as do patients with other gross rearrangements. At least thirty one point mutations have been described which cause severe, intermediate or mild type of disease.

\subsubsection{Mucopolysaccharidosis type III}

The MPS type III syndrome (Sanfilippo syndrome) is an inherited autosomal recessive lysosomal storage disease resulting from deficiency in the enzyme sulfamidase (SGSH) for the MPS IIIA type, in the alpha-N-acetylglucosaminidase (NAGLU) for the MPS IIIB type, in the alpha-glucosaminide $\mathrm{N}$-acetyltransferase for the MPS IIIC type, and in the Nacetylglucosamine 6-sulfatase for the MPS III D type. These enzymes participate to the sequential degradation of heparan sulphate (one of the major glycosaminoglycan) (Neufeld and Muenzer, 2001). The MPS III disease, which is one of the most frequent MPS, is characterized by severe central nervous system degeneration, resulting in progressive mental retardation for the most severe forms. After a period of seemingly normal development, patients exhibit a range of symptoms, including rapid loss of social skills with hyperactivity and aggressive behaviour, loss of learning ability, disturbed sleep patterns, hirsutism, coarse facies, and diarrhea. Fatal issue occurs in severely affected children in the mid- to late-teenage years, usually as a result of respiratory infection (Cleary and Wraith, 1993).

A total of 62 mutations have now been defined for MPS IIIA, the most frequent MPS III, consisting of 46 missense/nonsense mutations, 15 small insertions/deletions, and one splice site mutation. A total of 86 mutations have been identified in the NAGLU gene of MPS IIIB patients; 58 missense/nonsense mutations, 27 insertions/deletions, and one splice site mutation. Most of the identified mutations in the SGSH and NAGLU genes are associated with severe clinical phenotypes. Many of the missense, nonsense, and insertion/deletion mutations have been expressed in mammalian cell lines to permit the characterization of their effects on SGSH and NAGLU activity and intracellular processing and trafficking (Yogalingam and Hopwood, 2001).

\subsubsection{Mucopolysaccharidosis type VII}

Mucopolysaccharidosis VII (MPS VII) is caused by the deficiency of the enzyme beta-Dglucuronidase (GUS). This enzyme hydrolyses terminal glucuronic acid residues from glycosaminoglycans dermatan and heparan sulfate, chondroitin- 4 and -6 sulfate (Neufeld and Muenzer, 2001). The clinical picture shows a wide spectrum of severity and resembles that of MPS I and MPS II. Patients suffer from skeletal dysplasias, hepatosplenomegaly, and moderate mental retardation. Intelligence can be normal in late onset cases (Neufeld and Muenzer, 2001). In addition a severe neonatal form of MPS VII exists, which is already present during pregnancy as a hydrops fetalis (Wu and Sly, 1993). The cDNA (Oshima et al., 1987) and the beta-D-glucuronidase gene have been cloned (Miller et al., 1990). So far, 49 unique disease-causing mutations were determined in the GUS gene, including nine novel mutations (eight missense and one splice-site). This heterogeneity in GUS gene mutations contributes to the extensive clinical variability among patients with MPS VII (Tomatsu et al., 2009). 


\subsection{Pathophysiology, central nervous system and blood brain barrier issues}

\subsubsection{Pathophysiology}

A lysosomal defect leads to the accumulation of undegraded material, thus causing cell and organ dysfunction. Many investigations in a great number of tissues and organs have been carried out over the years, in order to explain how substrate accumulation results in disease. From these studies it has been realized that there are many factors playing a role in the pathophysiology of lysosomal storage disorders. For example, it is well known that, in Gaucher disease, the macrophages, which are activated by the storage of glucosylceramide, release a large number of cytokines or chemokines that have inflammatory effects (Hollak et al., 1997). Other investigations have provided evidence that inflammatory processes also contribute significantly to neurodegeneration in gangliosidoses. The report by Wada et al. (2000) demonstrated macrophage/microglial activation in the brain of a Sandhoff mouse model and in human Sandhoff brain implicating a neuro-inflammatory component in this disorder. In addition, Jeyakumar et al. (2003) has analysed the expression of inflammatory markers in mouse models of GM2- and GM1-gangliosidosis and found a significant elevation of MHC class II, CD68, CD4, CD8 and of cytokine production in the brain of affected animals. The observation that the increase of these mediators was accompanied by progressive microglial activation and expansion supports the hypothesis that inflammation is the major cause of neurodegeneration in gangliosidoses. This microglial activation is a characteristic shared by numerous neurodegenerative diseases (Minagar et al., 2002) and other lysosomal diseases, such as MPS I, MPS IIIB (Ohmi et al., 2003), Niemann-Pick type C (German et al., 2002), Krabbe disease (Wu et al., 2000), MPS VII (Richard et al., 2008) and MPS IIIA (Arfi et al., 2011).

Astrocytosis, like microglial activation, has also been widely described in neurodegenerative disorders (Wu and Proia, 2004; Tsuji et al., 2005; Arfi et al., 2011) and could be triggered by the release from activated macrophages of several cytokines and neurotrophic factors, such as MIP1 $\alpha$ and IL1 $\beta$ (Giulian et al., 1988,Wang and Shuaib, 2002).

An inflammatory process also seems to play a role in the development of joint and bone disease in mucopolysaccharidoses. Simonaro et al. (2005) showed that connective tissue cells are stimulated by inflammatory cytokines and nitrite oxide in animal models of MPS VII, analogous to the situation in arthritis. The brain of patients with neuronopathic forms of Gaucher disease contain not only an increased concentration of glucosylceramide, but also of glycosylsphingosine (glucosylceramide devoid of the $N$-acetylated fatty acid) (Orvisky et al., 2000). Glycosylsphingosine is known to be toxic to cells, and was therefore suggested to be the primary cause of the pathology (Orvisky et al., 2000). However, according to the work of Pelled et al. (2000) in post-mortem human brain from Gaucher disease patients, the level of glycosylsphingosine does not appear to be high enough to explain the involvement of central nervous system in type II and type III Gaucher disease. In the same study, the authors demonstrated that in the microsomal fraction of the patient's brain agonist-induced calcium release was significantly enhanced, as compared to control brains. Since elevated $\mathrm{Ca}^{++}$results in enhanced sensitivity to agents that induce cell death and apoptosis, it has been suggested that disturbance of calcium homeostasis may be a significant mechanism responsible for neuropathophysiology in acute neuronopathic Gaucher disease. Also, in animals affected by Gaucher, Sandhoff or Niemann-Pick diseases, a defective regulation of intracellular calcium has been shown to be an important pathogenic factor (Ginzburg et al. 2004; Arfi et al., 2006). 
Furthermore, a clear oxidative stress was observed in several neurological lysosomal storage diseases. Other studies previously highlighted the realease of reactive oxygen species (ROS) and/or the increased expression of components of the phagocyte NADPH oxidase in GM1 gangliosidosis (Jeyakumar et al., 2003), MPS IIIB (Villani et al., 2007), MPS I (Reolon et al., 2009), Batten disease (Benedict et al., 2007), or MPS IIIA (Arfi et al., 2011). It is still not defined whether the previously reported and presently observed oxidative imbalance is triggered by lysosomal dysfunction (Butler and Bahr, 2006), by autophagy impairment as recently described in MPS IIIA and Multiple Sulfatase Deficiency mouse models (Settembre et al., 2008), or is a secondary result from microglial activation. Nevertheless, it seems clear that these oxidative alterations may enhance damages in the brain cells, and may contribute to cognitive impairment as well as neurodegeneration through decline in synaptic integrity.

In summary, although we presently do not completely understand the pathophysiology of lysosomal storage disorders, there is no doubt that accumulation of storage material is the first pathogenic factor which triggers secondary structural and biochemical alterations, thereby leading to disease initiation and progression. Removal of this toxic storage material should be the first therapeutic goal.

\subsubsection{Turnover and trafficking of lysosomal enzymes in the central nervous system}

The lysosomal storage diseases (LSDs) affecting the central nervous system (CNS) pose the greatest challenges in treatment. An understanding of lysosomal enzyme transfer in the CNS, and how this is perturbed in these disorders, is therefore essential to successful treatment, and merits separate consideration.

Microglia represents the resident brain population of macrophages (van Furth et al., 1972; Naito et al., 1996). Microglial cells have many characteristics of macrophages, including the presence of hydrolases (Ling, 1977). They are derived from circulating blood monocytes that invade the brain early in postnatal life and become amoeboid microglia, which then differentiate into ramified microglia. Postnatally, microglial cells are continuously replaced by blood-bone monocytes that cross the blood-brain barrier (BBB) into the brain parenchyma. As they contain acid hydrolases, it has been postulated that the secretionuptake machinery applies to microglia and the surrounding neurones. That is to say, a proportion of lysosomal enzymes is secreted out of microglia and is available for recapture by the surrounding neurones. Direct experimental evidence of neuronal uptake of lysosomal enzymes has been shown by the reversal of storage in neural cells surrounding a graft of genetically corrected fibroblasts in the mucopolysaccharidoses VII (MPS VII) mouse brain (Taylor \& Wolfe, 1997). A gene therapy strategy also showed neuronal uptake, using a lentiviral vector in murine embryonic Sandhoff neurons (Arfi et al., 2006).

However, local secretion and uptake of lysosomal enzymes is not their only mode of transfer in the CNS. Axonal transport also occurs (Passini et al., 2002) and is probably an important mechanism for transfer to distant sites. Exactly what proportion of secreted lysosomal enzyme undergoes axonal transport is not known. However, it is a potentially important therapeutic route.

The origin of the substrate may differ inside and outside the CNS. This may explain why some patients with a similar enzyme deficiency have neurological involvement while others do not. Gaucher's disease is a good example of this. Patients with type I Gaucher's disease, 
do not have neurological involvement (non-neuronopathic), while patients with types II and III do (neuronopathic). Patients with the neuronopathic forms of Gaucher's disease have increased levels of the substrate glucosylceramide (GCS) in the brain. Glucosylceramide is derived from two sources. Inside the CNS it is derived predominantly from gangliosides, while elsewhere it is derived predominantly from the breakdown of blood cells. In type I patients, the degradation of blood cell derived glucosylceramide is blocked, but there is sufficient enzyme activity in the CNS to break down ganglioside-derived glucosylceramide, thus preventing its accumulation in the brain (Brady et al., 1993). In types II and III, however, there is less residual lysosomal enzyme activity (Brady, 1966), which is insufficient to degrade ganglioside-derived GCS in the CNS (Brady et al., 1965, 1993; Zhao et al., 2003).

\subsubsection{The blood-brain-barrier (BBB)}

The delivery of many potentially therapeutic and diagnostic compounds to specific areas of the brain is restricted by the blood-brain barrier, the blood-CSF barrier, or other specialised central nervous system (CNS) barriers. These brain barriers are now recognised as a major obstacle to the treatment of most brain disorders. The blood-brain barrier (BBB) is constituted by the endothelial cells of the brain capillaries. These cells are linked by tight junctions that form an effective barrier to paracellular aqueous diffusion (Brightman \& Reese, 1969; Kniesel \& Wolburg, 2000). Such junctions do not exist in the capillary endothelial cells of the peripheral circulation. This difference is thought to be the result of close apposition to both astrocytes and pericytes, both of which are tightly applied to the basement membrane of the cerebral capillaries (Kacem et al., 1998). Astrocytes have end feet, which spread in a network around the capillaries. The BBB also forms an electrical barrier in the form of a transendothelial electrical resistance (Begley \& Brightman, 2003).

It can be readily seen, therefore, that the BBB effectively prevents most polar bloodborne solutes from crossing. Yet monocytes cross the BBB and differentiate into microglia. Migration is significantly inhibited by the addition of blocking antibodies to intercellular adhesion molecule-1, very late antigen-4 integrin, and monocyte chemoattractant protein (CCL-2/MCP-1), or treatment with tissue inhibitor of metalloproteinase (Seguin et al., 2003). These results support the concept that monocyte-endothelial cell interactions are somehow responsible for monocyte migration across the BBB.

\section{Therapeutic strategy which aims at restoring enzyme activity}

Until now, no treatment is available for patients with neurological lysosomal storage diseases (LSDs), leading to the only option of prenatal diagnosis for high-risk families, thus avoiding the birth of diseased children. The families, who do not have this option, have to overcome the fatality of a rapid death of their children.

The availability of relevant animal models of these diseases has enabled the development of innovative therapeutic approaches. The orphan medicine status for these pathologies has interested a few biopharmaceutical and biotechnologies companies. Previously, substitutive therapies, allowing enzymatic restoration have been developed and successfully used in patients with Gaucher or Fabry diseases, as well as several MPS. Other strategies can also be imagined, such as the use of chaperone molecules, bone marrow transplantation, as well as gene and cell therapies. 
Depending on the enzymatic default, different approaches can be put in place: either the provision of the missing enzyme or the protein stabilization if the deficiency is due to a default in the protein stability. Other approaches can facilitate the provision of exogenous enzyme and are based on the secretion-uptake capacity of lysosomal enzymes, in order to obtain a trans-correction of deficient cells. Another major argument is the assumption that a partial correction (5-10\%) could be enough to sustain a normal phenotype. This idea is based on pseudodeficiencies: some patients, who do not have any clinical symptom, have an enzymatic activity collapsed at 10\% of the normal activity (Cao et al., 1997; Leinekugel et al., 1992).

\subsection{Enzyme replacement therapy}

Enzyme replacement therapy (ERT) is certainly the earliest therapeutic approach which has been successful in lysosomal storage diseases (LSDs) at the clinical level. De Duve, in 1964, was the first to suggest the concept of exogenous enzyme supplementation (de Duve, 1964). The first clinical trials were performed in the 1970s, using intravenous injections of human protein. Rapidly, the investigators realised that the central nervous system (CNS) would be difficult to reach, due to the blood brain barrier. Thus, they focused on non-neurologic LSDs.

Roscoe Brady developped the ERT for Gaucher type I disease. In the early 1990s, the first results showed that one weekly infusion of 2 to $3 \mathrm{mg} / \mathrm{kg}$ enzyme modified in its glycosylation, could lead to a significant reduction of the substrates accumulation and to the disappearance of clinical symptoms (Barton et al., 1990). These trials were sponsored by a biotechnologies company, Genzyme, and led to a marketing authorization in 1991 in Europe, Israel and USA.

The recent development of molecular biology and the cloning of cDNA of main lysosomal hydrolases, have led to the large-scale production of the recombinant protein. The generation of disease mouse models by homologous recombination allowed ERT test in preclinical studies. Thanks to these technological progresses, clinical trials were initiated by three biopharmaceutical companies: Genzyme®, BioMarin Pharmaceutical Inc, and Transkaryotic Therapies (now Shire Pharmaceuticals), for several disorders such as Fabry disease, mucopolysaccharidoses (MPS) I, II, VI, and Pompe disease, leading to the commercialization of a therapy for these diseases, improving most of the peripheric symptoms in these disorders . For example, the Food and Drug Administration (FDA) has approved the orphan medicine Aldurazyme ${ }^{\circledR}$ (Laronidase) in May 2003, for the treatment of certain forms of mucopolysaccharidosis type I (MPS I). Aldurazyme ${ }^{\circledR}$ is a version of the human form of the enzyme alpha-L-iduronidase. Treated patients exhibited significant improvements in their lung function and their ability to walk. At the molecular level, Aldurazyme ${ }^{\circledR}$ reduced carbohydrates accumulation (FDA Talk Paper, 2003).

For several years, enzyme replacement therapy (ERT) based on intravenous injection of recombinant enzyme, whose deficiency causes the disease, has been used to treat MPS I (Kakkis et al., 2001; Wraith et al., 2004), MPS II, and MPS VI (Muenzer et al., 2002; Harmatz et al., 2006; Muenzer et al., 2006), and it appears that an analogous therapy could be also efficient for MPS IVA (clinical trial on going) (Tomatsu et al., 2008; Dvorak-Ewell et al., 2010). This therapy is effective for treating somatic symptoms of MPS I, MPS II, and MPS VI. 
However, intravenous administration of enzymes appears to be inefficient for CNS treatment because of the blood-brain barrier.

However, over the past few years, researchers have investigated high-dose ERT in animal models of a number of LSD, including MPS VII (Vogler et al. 2005), Krabbe disease (Lee et al., 2005), metachromatic leukodystrophy (MLD; Matzner et al., 2009) and MPS IIIA (Rozaklis et al., 2011). With the exception of the latter study in MPS IIIA mice, these reports demonstrate that high dose ERT can mediate reductions in neuropathology and, in some cases, improve neurological function. The mechanisms by which high-dose enzyme access the brain are not well understood, but several hypotheses have been advanced, such as carriage via blood-borne macrophages, saturation of M6P receptors, and increased plasma half-life.

To circumvent the BBB, the direct intracerebroventricular (i.c.v.) injection of lysosomal enzymes has been explored. Intrathecal enzyme replacement therapy (ERT) holds promise as a treatment for the central nervous system manifestations of lysosomal storage diseases, since treatment via the cerebrospinal fluid represents a potential method of delivering recombinant enzyme across the blood-brain barrier. All intra-cerebrospinal fluid ERT studies in mice have reported improved function, and reduced neuropathology has also been described in the brain of dog models (MPS I (Kakkis et al., 2004; Dickson et al., 2007), MPS IIIA (Hemsley et al., 2007, 2008, 2009). However, several questions remain regarding this approach, in particular which route of injection (ventricular, cisternal or lumbar) provides the most widespread distribution of enzyme in brain parenchyma; is bolus or sustained delivery of enzyme via an osmotic pump device preferable; and, finally, what is the optimal frequency of administration for each condition? This treatment approach is now in clinical trials (MPS I; NCT 00638547 and NCT 00852358; MPS II, NCT 00920647 and MPS IIIA; NCT01155778; see www. clinicaltrials.gov).

\subsection{Bone-Marrow transplantation}

Cells that are primarily involved in the systemic manifestations of many storage disorders are macrophages that arise from stem and progenitor cells in the bone marrow. Because of this etiology, bone marrow transplantation (BMT) has been tried in a number of metabolic disorders with varying degrees of success. If engraftment of healthy donor cells is successful and incapacitating graft-versus-host reactions do not occur, or if it arises and is properly controlled by immunosuppression, BMT can cure certain patients with type 1 Gaucher disease in whom the brain is not involved. However, difficulties in obtaining suitable donors, dangers associated with myeloablation, and the likelihood that recipients may require immunosuppression throughout their life raises serious concern about the advisability of BMT for lysosomal storage diseases diseases.

\subsection{Cell/stem cell and gene therapy}

As described above, enzyme replacement therapy has become a therapeutic option for some lysosomal storage disorders, but, has been shown to be of limited efficacy, especially regarding the effect on bone and brain manifestation. Furthermore, the recurring administration of an exogenous protein bears the risk of inducing an immune response that may interfere with the therapeutic enzyme or even neutralize its activity. Gene-based 
therapy may overcome this problem, as it may allow constant delivery of a therapeutic protein to the whole body or to targeted organs, as for example the bone or the brain. For several reasons lysosomal storage disorders are excellent candidates for therapy by gene transfer (Sands and Davidson, 2006). At first, they represent generally well-characterized single gene disorders, secondly they are not subject to complex regulation mechanisms, and an enzyme activity of only $15-20 \%$ of the normal level is sufficient for clinical efficacy. There are two ways to deliver a gene into the organism, the in vivo and the ex vivo technique.

\subsubsection{In vivo gene therapy}

To establish a sustained source of therapeutic protein within the body for metabolic correction in peripheral organs, the liver has been used as a depot organ. In animal experiments several vehicles such as adenoviral adeno-associated, retroviral and lentiviral vectors were used for efficient liver transduction. By such strategies, the liver produced large amounts of therapeutic enzyme that was secreted into the bloodstream and recaptured by the target organs by the mannose-6-phosphate receptor. The efficacy of this technique has been demonstrated in several animal models. The team of Mango and co-workers used mice and dogs affected by MPS VII (beta-glucuronidase deficiency, Sly disease) for their experiments. Neonatal intravenous injection of a retroviral vector (RV) expressing canine beta-glucuronidase resulted in hepatocyte transduction, and secreted enzyme was taken up from blood by other organs. The treated animals did not develop major signs of the disease, such as cardiac abnormalities or corneal clouding and displayed significant amelioration of the skeletal, cartilage and synovial disease (Mango et al., 2004).

Non viral methods were also tested by our group to target the liver of MPS VII mice, using hydrodynamic injections of plasmid containing the beta-glucuronidase cDNA, leading to improvements in both peripheral and brain manifestations of MPS VII disease (Richard et al., 2009). The surprising biochemical correction observed in brain, while only the liver was producing the enzymes in this particular study, points to the possibility of the therapeutic enzymes crossing the blood-brain barrier (BBB) when continuously produced at the periphery. Although this effect might be related to inflammation-mediated BBB leakage in the particular MPS VII mouse model used, these results provide a rationale and hope for the treatment of other neurologic LSD.

In an alternative to the "liver" approach, Li et al. (2002) used the lung as a depot organ for delivering beta-galactosidase into the heart and kidney of mice affected by Fabry disease.

Long-term analysis of several gene transfer experiments has shown the occurrence of immune response leading to clearance of the transduced cells and/or loss of enzyme activity (Di Domenico et al., 2005). However, it could be demonstrated that the immune response may be prevented by using hepatocyte-specific promoters that restrict transgene expression to parenchymal cells of the liver and avoid transgene expression within antigen-presenting cells (Follenzi et al., 2004).

In spite of the results obtained on MPS VII mice by our group (Richard et al., 2009, the beneficial effect of gene transduction into the liver or other peripheral tissues is generally considered to be restricted to peripheral organs, as the secreted enzyme will not cross the blood brain barrier. Therefore, vector delivery systems have been developed for direct in vivo gene transfer into the CNS. Desmaris and co-workers injected into the brain of MPS I 
mice a single dose of gene transfer vectors derived from adeno-associated virus (AAV) coding for human alpha-iduronidase. The procedure prevented the accumulation of GM2 and GM3 gangliosides, which apparently contributes to neuropathology. Storage material, which already was present at the time of treatment, disappeared from both brain hemispheres (Desmaris et al., 2004). Similar results have been obtained by Ciron et al. (2006) who used MPS I dogs as an animal model. In their experiments adeno-associated virus vectors coding for human alpha-iduronidase was injected into the animal brain. The procedure prevented glycosaminoglycan accumulation and resulted in significant reduction of neuropathology throughout the brain. However, since deficient dogs raised antibodies against AAV in response to infusion, intracerebral vector injections had to be combined with an immunosuppressive treatment. More recently, a widespread enzymatic correction of CNS tissues was obtained after one single intracerebral injection of therapeutic lentiviral vector in leukodystrophy mouse models (Lattanzi et al., 2010). Several other teams have shown promising results in MPS IIIB, MPS I, MPS IIIA mouse or dog models, using either intracranial AAV-mediated gene therapy (Heldermon et al., 2010; Ellinwood et al., 2011; McIntyre et al., 2010; Fraldi et al., 2007) or intracisternal AAV gene transfer (Fu et al., 2010).

Brooks et al. used recombinant feline immunodeficiency virus (FIV)-based vectors for transfer of the beta-glucuronidase gene into the brain of adult MPS VII mice. In both hemispheres a modest reduction of storage material or even a correction of characteristic cellular pathology was detected. Although the affected mice before treatment had already shown significant deficits in spatial learning and memory there was a dramatic functional improvement as a consequence of the gene therapy (Brooks et al., 2002).

Recent studies have shown that the fusion of the lysosomal enzyme beta-glucuronidase with a peptide, the protein transduction domain from HIV Tat, allows for mannose-6-phosphate independent uptake in vitro and alters the biodistribution of the enzyme after systemic delivery in a mouse model for MPS VII (Orii et al., 2005). However, in the brain of the treated animals only a slight increase of enzyme activity was observed after intravenous injection of the glucuronidase-Tat chimeric protein when expressed from viral vectors (Xia et al., 2001). The efficacy of a therapeutic lentiviral vector was also studied in MPS IIIA (McIntyre et al., 2008) and in MPS IIIB mouse models (Di Domenico et al., 2009) and showed to have the capacity to alleviate most disease manifestations.

Overall, gene transfer methods have shown very promising results in several neurological LSDs at the preclinical level. In consequence, several clinical trials (Phase I/II) have been launched and more are projected, as illustrated in Table 1. A phase I clinical trial in CLN2 patients, using intracranial AAV-based gene therapy, showed no toxicity, but no efficiency at this stage (Souweidane et al., 2010). A Phase I/II trial for MPS IIIA patients has just been authorized and will assess the efficacy of several intracranial injections of a therapeutic AAV vector. Another clinical trial is in preparation for MPS IIIB patients.

\subsubsection{Ex vivo gene therapy and cell therapy}

Based on the positive clinical experience with bone marrow transplantation in some lysosomal storage disorders (LSDs), hematopoietic stem cell-mediated gene therapy was considered as an attractive alternative for the treatment of LSDs. Gene transfer strategies aimed at correcting the genetic defect in the hematopoietic stem cells may have significant advantages compared with conventional allogeneic stem cell transplantation. Because 
autologous cells are used for ex vivo gene therapy, transplant-related morbidity and mortality are reduced as there is no risk of graft-versus-host disease. Furthermore, genetically modified cells may express higher levels of the therapeutic enzyme and become more effective than wild-type cells.

For ex vivo therapy, stem cells of the patient are transfected with the gene and thereafter returned to the body. The efficacy of this procedure has been demonstrated in many experiments on LSD animals, for example in MPS I mice. Bone marrow from affected male donor mice was transduced with human iduronidase cDNA by using an MND retroviral vector and transplanted into 6-8 week old, lethally irradiated affected female mice. The procedure resulted in correction of pathology of liver, spleen, cartilage cells and even of kidney, choroid plexus and thalamus, as seen by light microscopy. Electron microscopy showed the presence of some normal neurons in the cortex. The partial correction of brain pathology was attributed to migration of donor hematopoietic cells, demonstrated by the presence of the $\mathrm{Y}$ chromosome and of normal microglia in the brain of mice receiving iduronidase cDNA (Zheng et al., 2003).

As discussed above, microglial cells play a major role in the pathogenesis of CNS involvement in many lysosomal storage disorders (Ohmi et al., 2003; Wada et al., 2000). These cells apparently represent the primary site of lipid storage resulting in cell activating and secretion of cytokines and pro-inflammatory molecules that trigger the focal inflammation, demyelination, and neurodegenerative features of these disorders. Therefore, microglia should be the primary target cell type in therapeutic strategies for LSDs.

Gene-marking studies in animal models have shown that hematopoietic stem cells significantly contribute to the turnover of CNS-resident microglia: hematopoietic stem cells, transfected with lentiviral vectors encoding the green Fluorescent protein (GFP), were extensively engrafted in the CNS and peripheral nervous system of mice (Biffi et al., 2004). In mice affected by metachromatic leukodystrophy, hematopoietic stem cells transduced ex vivo with the arylsulfatase A gene, resulted in full reconstitution of enzyme activity. Moreover, by this procedure functional deficits such as motor conduction impairment and delayed learning could be prevented (Biffi et al., 2004). Similar results have been reported by Matzner and Gieselmann (2005).

Although gene therapy studies performed in animal models are rather promising, many important issues regarding safety and efficacy of this therapeutic strategy need to be addressed before clinical trials can be initiated. To achieve high enzyme activity a high level of transgene expression by hematopoietic stem cells might be required, and the integration of a large amount of vectors increases the risk of integrated-dependent adverse events. The occurrence of adverse events in patients with an X-linked severe combined immunodeficiency who were treated by gene therapy led to major attention regarding mutagenesis and leukemogenesis related to retroviral integration (Hacein-Bey-Abina et al., 2003). Furthermore, retroviral and lentiviral vectors tend to be integrated close to expressed genes, thus increasing the likelihood of transcriptional interference between the vector and flanking endogeneous genes (De Palma et al., 2005). This interference may lead to silencing of the endogeneous gene targeted by the integration and also to transcriptional deregulation of the endogenous genes that are located near the integration site. Such interference may be avoided by using late-generation lentiviral vectors that are self-inactivating with transcriptionally inactive long terminal repeats (LTRs) on transduction, which express the transgene from an internal promoter of choice. Furthermore, the risk of insertional 
mutagenesis by retroviral and lentiviral vectors may be different due to their biological differences. Table 1 summarises the neuronopathic LSDs for which hematopoietic stem cell therapy (HSCT) is considered to be either a first line or optional treatment for preventing or arresting neurocognitive decline. Additionally, three clinical trials are underway to assess the efficacy of gene-modified HSCT in MPS II, MPS VII and MLD (Table 1).

Direct engraftment of exogenous cells into the CNS is a therapeutic strategy first examined 20 years ago, however, to our knowledge, only one clinical trial has been completed using this treatment method (www.clinicaltrials.gov.; NCT00337636), in infantile and late-infantile neuronal ceroid lipofuscinosis patients aged 18 months to 12 years using unmodified humanderived neural stem cells (Tamaki et al., 2009). Another clinical trial using the same cell type is in the recruitment phase (NCT01238315) and younger patients will be enrolled this time (6 months to 6 years of age). Whilst there is pre-clinical evidence from the mid-1990 s to support the potential success of this approach, e.g. Lacorazza et al. (1996; Tay-Sachs mice); Snyder et al. (1995; MPS VII), problems such as the invasive nature of the treatment, ethical debates regarding some sources of donor cells and the need for widespread replacement of lysosomal proteins in brain, have hampered the translation of this therapeutic approach.

\begin{tabular}{|l|l|l|l|l|}
\hline Disease & $\begin{array}{l}\text { Clinical trial } \\
\text { stage }\end{array}$ & Vector & Delivery method & Contacts and trial details \\
\hline Gene Therapy & Phase I, open & AAV2 & Intracerebral injection & $\begin{array}{l}\text { Ronald Crystal, New York, } \\
\text { USA US-0619, NCT } \\
\text { 00151216 (Souweidane et } \\
\text { al., 2010) }\end{array}$ \\
\hline LINCL & Phase I, open & AAV-rh10 & Intracerebral injection & $\begin{array}{l}\text { Ronald Crystal, New York, } \\
\text { USA US-0977 NCT } \\
\text { 01161576 }\end{array}$ \\
\hline LINCL & \multicolumn{5}{|l|}{} \\
\hline HSC Therapy & $\begin{array}{l}\text { Routine clinical } \\
\text { use }\end{array}$ & Nil & $\begin{array}{l}\text { i.v. infusion of cells harvested } \\
\text { from compatible donor }\end{array}$ & $\begin{array}{l}\text { Reviewed in Boelens et al. } \\
\text { (2010) }\end{array}$ \\
\hline $\begin{array}{l}\text { alpha- } \\
\text { manosidosis }\end{array}$ & Clinical & Nil & i.v. infusion & See Boelens et al. (2010) \\
\hline Fucosidosis & Clinical & Nil & i.v. infusion & See Boelens et al. (2010) \\
\hline $\begin{array}{l}\text { MLD late } \\
\text { onset }\end{array}$ & Clinical & Nil & i.v. infusion & See Boelens et al. (2010) \\
\hline $\begin{array}{l}\text { Krabbe } \\
\text { disease }\end{array}$ & Clinical & Nil & i.v. infusion & See Boelens et al. (2010) \\
\hline Gene-modified cell therapy & $\begin{array}{l}\text { Phase I/II, } \\
\text { closed }\end{array}$ & Retrovirus & $\begin{array}{l}\text { Ex vivo modification of } \\
\text { autologous HSC, i.v. infusion }\end{array}$ & $\begin{array}{l}\text { L. Lashford, Manchester, } \\
\text { UK UK-0011 }\end{array}$ \\
\hline MPS II & Phase I, open & Lentivirus & $\begin{array}{l}\text { Ex vivo modification of } \\
\text { autologous HSC, i.v. infusion }\end{array}$ & $\begin{array}{l}\text { Mark Sands, St Louis, USA } \\
\text { US-0758 }\end{array}$ \\
\hline MPS VII & Phase I/II, open & Lentivirus & $\begin{array}{l}\text { Ex vivo modification of } \\
\text { autologous HSC, i.v. infusion }\end{array}$ & $\begin{array}{l}\text { Alessandra Biffi, Milan, } \\
\text { Italy IT-0019 }\end{array}$ \\
\hline MLD & Phase I, open & Retrovirus & $\begin{array}{l}\text { Intraperitoneal delivery of } \\
\text { autologous exogenously modified } \\
\text { fibroblasts }\end{array}$ & $\begin{array}{l}\text { Alain Fischer, INSERM } \\
\text { Paris, France FR-0005 }\end{array}$ \\
\hline MPS I & &
\end{tabular}

Table 1. Summary of human clinical trials investigating central nervous system (CNS)directed gene therapy or haematopoietic stem cell (HSC) approaches for treatment of CNS disease in lysosomal storage diseases (from

http://www.wiley.com/legacy/wileychi/genmed/clinical/, www.clinicaltrials.gov, Hemsley \& Hopwood, 2011) 


\subsection{Chaperone therapy}

Several mutations lead to a wrong protein folding, causing instability and a decreased enzymatic activity, or a default in the routing of proteins. Small molecules chaperones with a low molecular weight can be used in these cases. These molecules can cross the blood brain barrier and can easily diffuse through the tissues, underlining their interest in the mild forms of lysosomal storage diseases (LDSs) with neurological involvement.

Two different types of chaperones exist: the chemical chaperones, which are non specific molecules which stabilize mutant proteins misfolded in the ER (Sato et al., 1996), and pharmacological chaperones, which are enzyme-specific substrates analogues, and which stabilize the proteins during their synthesis. In the last few years it has been found that imino-sugars do not only act as enzyme inhibitors, but also have an effect as so-called chaperones. Chaperones are a part of a cell system that has the task to control the quality of newly synthesized proteins. This machinery, which involves the ubiquitin system and proteosomes, eliminates misfolded or unstable mutant proteins. Under physiological conditions, chaperones restore the native conformation of misfolded proteins. It has been estimated that up to $30 \%$ of normal proteins do not become functionally active, but in contrast are misfolded and consequently aggregate and are rapidly (within minutes) degraded by the cell's quality control machinery (Bernier et al., 2004). In genetic disorders, certain missense mutations and some small in-frame deletions may cause polypeptide misfolding, but may not (or only slightly) impair the functionally essential domains of the mutant protein (the active site, receptor-binding site, etc (see Figure 1).

A
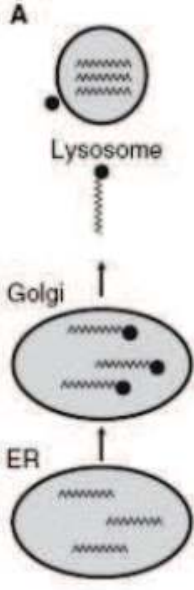

B
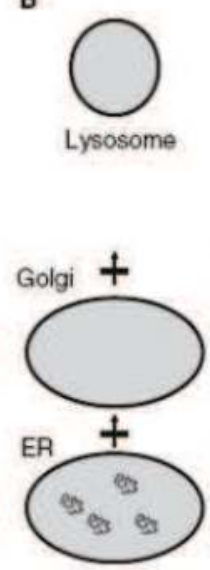

C
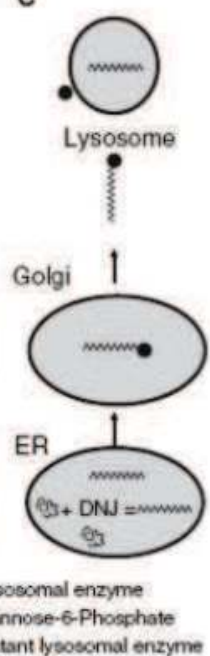

Fig. 1. A: Normally, the lysosomal enzymes are synthesized in the endoplasmic reticulum (ER) and transport to the Golgi apparatus, where they receive the mannose-6-phosphate marker that is essential for receptor-mediated sorting into the lysosomes. B: The mutant enzyme is misfolded and retained in the ER, enzyme activity is lacking in the lysosome. C: N-butyldeoxynojirimycin increases the stability of the mutant enzyme that now is able to enter the Golgi apparatus and- after binding the mannose-6-phosphate receptor- becomes active within the lysosome (from Beck, 2007). 
Pharmacological chaperones, such as substrate analogues, may facilitate the stabilization of misfolded proteins and imino-sugars such as deoxynojirimycin-analogues function as chaperones. The effect of $N$-(n-nonyl)deoxynojirimycin $(\mathrm{NN}-\mathrm{DNJ})$ on fibroblasts from a Gaucher patient who had the common N370S mutation was investigated by Sawkar et al. (2002). The addition of sub-inhibitory concentrations of NN-DNJ to the cultured cells resulted in a twofold increase in the activity of beta-glucocerebrosidase. The NN-DNJ chaperone also increased wild-type beta-glucocerebrosidase activity, but not that of the L444P mutation, which in general is associated with neurological involvement.

In GM2-gangliosidoses (Tay-Sachs and Sandhoff disease), the chronic adult forms have an enzyme activity of approximately $5 \%$, and there are healthy individuals who exhibit only $10 \%$ of normal levels. Considering that in late-onset variants of GM2-gangliosidoses almost all disease-associated missense mutations do not affect the active site but lead to misfolding of the mutated protein, the influence of several known hexosaminidase inhibitors, such as $\mathrm{N}$-Acetyl-galactosamine (GalNAc), Deoxynojirimycin (DNJ), Castanospermine (CAS) or NAcetyl-glucosamine-thiazoline (NGT), was studied (Tropak et al., 2004). By the addition of these inhibitors to cultured fibroblasts from an adult Tay-Sachs patient who carried the mutation G269S, an increase in the activity levels of intralysosomal hexosaminidase A well above the critical $10 \%$ of normal levels could be achieved. A similar effect was observed in fibroblasts from an adult Sandhoff patient (Tropak et al., 2004).

Other studies are in progress to identify new chemical or pharmacological chaperones for LSDs (Ficko-Blean et al., 2008; Feldhammer et al., 2009; Valenzano et al., 2011). In summary, small molecule chemical chaperones may be therapeutically useful for various lysosomal storage disorders caused by mutant but yet catalytically active enzymes.

\section{Therapeutic strategy focused on reducing substrate production and/or accumulation}

\subsection{Substrate reduction therapy}

Substrate reduction therapy represents a novel approach for the treatment of glycosphingolipidoses. Whereas enzyme replacement therapy is aimed at removal of storage material accumulating within the lysosome, the principle of substrate reduction therapy is to partially inhibit the biosynthetic cycle, in order to reduce substrate influx into the catabolically compromised lysosome. The concept that an inhibition of ceramide glucosyltransferase, which represents the key enzyme in glycosphingolipid (GSL) synthesis, could lead to reduction in GSL concentration, was originally proposed by Radin (1996). As best candidates for ceramide glucosyltransferase inhibition, emerged the imino-sugars that were already known to reduce the activity of the enzyme beta-glucosidase.

First clinical trials allowed the assessment for efficacy in type I Gaucher disease (Cox et al., 2000). In this study, 28 adult Gaucher patients who were unable or unwilling to receive enzyme replacement therapy were treated with $\mathrm{N}$-butyldeoxynojirimycin (100 $\mathrm{mg}$ three times daily). At 12 months, mean liver and spleen volumes were significantly lowered by 12 and $19 \%$, respectively. Hematological parameters showed a slight improvement. The most frequent adverse effect was diarrhea, which occurred in $79 \%$ of patients shortly after the start of treatment. Although the occurrence of tremor and peripheral neuropathy in patients on $\mathrm{N}$-butyldeoxynojirimycin and the development of cognitive dysfunction in a single case 
raised a number of issues regarding safety of this drug (Pastores and Barnett, 2003), the proof of principle allowed for further clinical studies to evaluate low dose administration (Heitner et al., 2002) and long-term treatment (Elstein et al., 2004). In the latter extension study statistically significant improvement in all major efficacy endpoints were achieved indicating that treatment with $\mathrm{N}$-butyldeoxynojirimycin was increasingly effective with time. In this trial no new case of peripheral neuropathy was reported and diarrhea and weight loss decreased. $\mathrm{N}$-butyldeoxynojirimycin's action on glucosylceramide synthesis is illustrated in Figure 2.
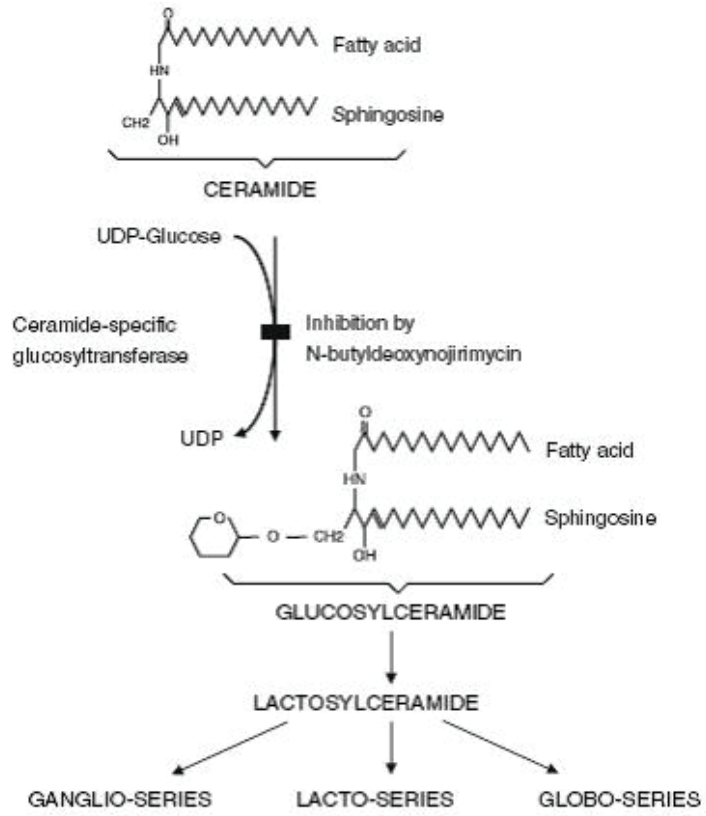

Fig. 2. N-butyldeoxynojirimycin inhibits the synthesis of glucosylceramide, the precursor of all glucosphingolipids (from Beck, 2007).

In 2003 an independent international advisory group made a statement regarding the role of $N$-butyldeoxynojirimycin in the treatment of type I Gaucher disease (Cox et al., 2003). The advisory council considered the following patient categories to be eligible for such treatment: (i) adult patients with mild or moderate symptomatic Gaucher disease who are unwilling or unable to receive or to continue ERT, and (ii) patients with persistent signs of disabling disease activity despite maximal enzyme dosing. In these patients the drug may be applied in combination with ERT.

As glucosylceramide represents the precursor of several glycosphingolipids such as globosides and gangliosides, $N$-butyldeoxynojirimycin was also considered as a treatment option for patients with GM1- or GM2-gangliosidoses. This assumption is also supported by the fact that this drug is a small molecule that is able to cross the blood-brain barrier (Lachmann et al., 2004). Jeyakumar et al. (1999) performed an experiment in a mouse model of Sandhoff disease (0 variant of GM2- gangliosidosis). Mice treated with this drug showed 
delayed symptom onset, reduced storage in peripheral tissues and in the brain, and increased life expectancy. Based on these positive experimental data, Bembi et al. (2006) investigated the clinical efficacy of $N$-butyldeoxynojirimycin in two patients with infantile Tay-Sachs disease (B variant of GM2-gangliosidosis). However, the enzyme inhibitor could not slow down the progressive clinical deterioration.

Niemann-Pick disease type C (NPC) is a genetic lipid storage disorder mostly caused by mutations in NPC1, a membrane protein involved in endosomal-lysosomal transport of lipids. In the brains of NPC patients, the gangliosides are the major storage lipids and there is evidence from the NPC mouse model that accumulation of gangliosides rather than of cholesterol leads to cellular dysfunction in neural tissue (Zervas et al., 2001). To evaluate this hypothesis, NPC mice were treated with $\mathrm{N}$-butyldeoxynojirimycin (Miglustat, Actelion). Treatment resulted in delayed onset of neurological dysfunction, increased life span and reduction of ganglioside accumulation in the brains of the animals. Nbutyldeoxynojirimycin was used for the first time in a patient with Niemann-Pick C disease type I in a study performed by Lachmann and co-workers (2004). The adult female received the drug at a dosage of $100 \mathrm{mg}$ once daily. After several months of treatment a decrease in pathological lipid storage was seen in her peripheral blood lymphocytes. Her clinical condition remained stable (Lachmann et al., 2004). Several clinical trials have since been conducted in humans using Miglustat, demonstrating mild clinical improvement or stabilization, with greater impact on earlier diagnosed populations. Miglustat is the only currently approved therapy for NPC disease and clearly slows disease progression with limited side effects (Wraith et al., 2009; Patterson et al., 2010; Galanaud et al., 2009; Patterson et al., 2007).

\subsection{Isoflavones-based therapy of MPS diseases}

More recently, the Wegrzyn's team has demonstrated that treatment with the isoflavone genistein [4', 5, 7-trihydroxyisoflavone or 5, 7-dihydroxy-3- (4-hydroxyphenyl)-4H-1benzopyran-4-one] (Figure3), impairs glycosaminoglycans synthesis and thus may represent an effective method of reducing GAG storage in MPS patient cells (Piotrowska et al., 2006). This inhibition has been proposed to be due to a genistein-mediated inhibition of kinase activity of the epidermal growth factor receptor (Piotrowska et al., 2006; JakóbkiewiczBanecka et al., 2009). Malinowska et al. (2009) recently described significant reductions of accumulated heparan sulphate substrate in liver of a mouse model of MPS IIIB using the tyrosine kinase inhibitor genistein. The tyrosine kinase inhibitory effect of genistein most probably affects the expression of genes encoding enzymes necessary for GAG synthesis. Nevertheless, this remains to be clearly established, as well as the mechanism of action of other flavonoid compounds which appearing to mediate their effect via an alternative pathway (Kloska et al., 2011).

Subsequent studies have indicated that genistein may be effective in treatment of mice suffering from MPS IIIB (one of four subtypes of MPS III) and MPS II, including improvement in CNS in short-term treatment of animals with the latter disease and complete correction of behavior in long-term treatment of animals with the former disease (Friso et al., 2010; Malinowska et al., 2009, 2010). In pilot clinical studies, it was demonstrated that the treatment of patients suffering from MPS IIIA and MPS IIIB with a genistein-rich isoflavone extract resulted in statistically important improvement of all tested 
parameters (when mean values from all patients were compared), including cognitive functions, as assessed by using a special psychological test (Piotrowska et al., 2008). After a 2-year follow-up of this pilot study, the results showed that, in 5 treated children, this genistein treatment might be interesting to improve cognitive functions and behavioral symptoms or at least stop their deterioration over a period of time (Piotrowska et al., 2011). The effects of genistein on neurological parameters in MPS animals and humans were assumed to be due to an ability of this isoflavone to cross the blood-brain-barrier, which was demonstrated previously (Tsai, 2005).<smiles>O=c1c(-c2ccccc2)coc2ccccc12</smiles>

Fig. 3. Isoflavone structure, numbering. Genistein $(5-\mathrm{OH}, 7-\mathrm{OH}, 4-\mathrm{OH})$ or daidzein $(7-\mathrm{OH}$, 4 '-OH) are e. g. members of the isoflavone family. Isoflavone differs from flavone (2-phenyl$4 \mathrm{H}$-1-benzopyr-4-one) in location of the phenyl group

This therapeutic approach is promising. However, it is also clear that further studies are necessary to optimize this procedure. For example, we have tested various isoflavones for their activities in correction of GAG lysosomal accumulation in MPS IIIA and MPS VII fibroblasts, and found that some of the tested compounds are as efficient as genistein in decreasing GAG storage in MPS cells, and that a combination of different compounds from this group may be more efficient than one single flavonoid (Arfi et al., 2010). Another study has shown the effects of other flavonoids (apigenin, daidzein, kaempferol and naringenin) on GAG synthesis (Kloska et al., 2011). Indeed, the Wegrzyn's team found that daidzein and kaempferol inhibited GAG synthesis significantly (Kloska et al., 2011). Moreover, these compounds were able to reduce lysosomal storage in MPS IIIA fibroblasts. Interestingly, although genistein is believed to inhibit GAG synthesis by blocking the tyrosine kinase activity of the epidermal growth factor receptor, they found that effects of other flavonoids were not due to this mechanism. Again, a combination of various flavonoids resulted in significantly more effective inhibition of GAG synthesis than the use of any of these compounds alone (Kloska et al., 2011). Altogether, these results suggest that combination of flavonoids can be considered as a method for improvement of efficiency of SRT for MPS III or other LSD.

\section{Complementary therapeutic strategies, based on downstream consequences of enzyme deficiency and substrate accumulation}

\subsection{Anti-inflammatory molecules}

Neurodegeneration has been observed in several lysosomal diseases, but the relationship between substrate accumulation and neurological disorder remains unclear. Inflammation is known to be implicated in numerous neurodegenerative diseases, and has been recently well characterized in murine models of GM1/GM2 gangliosidoses (Myerowitz et al., 2002, 
Jeyakumar et al., 2003), as well as in mouse models of Metachromatic Leukodystrophy (Hess et al., 1996), Niemann-Pick C disease (German et al., 2002), MPS I (Ohmi et al., 2003), MPS IIIB (Ohmi et al., 2003; Villani et al., 2007) and MPS IIIA (Fraldi et al., 2007). Moreover, our previous study on a mouse model of MPS VII showed an extensive upregulation of genes related to an inflammatory process dominated by activated microglia, astrogliosis and celldeath, suggesting that inflammation might participate in neurodegeneration (Richard et al., 2008).

Therefore, targeting brain inflammation represents a potential clinical intervention strategy. Indeed, several studies have recently shown that anti-inflammatory treatments, using nonsteroidal anti-inflammatory drugs (NSAIDs) significantly slowed the clinical course of both Sandhoff and Niemann-Pick type C1 diseases (Jeyakumar et al., 2003; Jeyakumar et al., 2004; Smith et al., 2009). It has also been shown by our group in the MPS IIIA mouse models, following-up several inflammation markers (Arfi et al., 2011). NSAID could also be combined with other therapies targeting the primary defect, aiming at additive or synergistic benefit. However, further studies are necessary to characterize and maybe correlate a potential clinical improvement to the molecular and biochemical effects observed in aspirin-treated mice (Jeyakumar et al., 2004; Smith et al., 2009). In addition, careful preclinical and clinical studies would be required to determine whether these findings extrapolate to the human disease.

\subsection{Anti-oxidative molecules}

A recent study by our group has evidenced a clear oxidative stress not only in MPS IIIA mouse brains, but also in MPS IIIA peripheral organs such as liver and spleen, as early as 6 months of age (Arfi et al., 2011). Other studies previously highlighted ROS release and/or increased expression of components of the phagocyte NADPH oxidase in GM1 gangliosidosis (Jeyakumar et al., 2003), MPS IIIB (Villani et al., 2007), MPS I (Reolon et al., 2009) or Batten disease (Benedict et al., 2007). It is still not defined whether the previously reported and presently observed oxidative imbalance is triggered by lysosomal dysfunction (Butler and Bahr, 2006), by autophagy impairment as recently described in MPS IIIA and Multiple Sulfatase Deficiency (MSD) mouse models (Settembre et al., 2008), or is a secondary result from microglial activation. Nevertheless, it seems clear that these oxidative alterations may enhance damages in brain cells, and may contribute to cognitive impairment as well as neurodegeneration through decline in synaptic integrity.

Beyond NSAID treatment, we have tested an anti-oxidant treatment (vitamin C) alone or in combination with aspirin in the MPS IIIA mouse model, but this treatment failed to show much benefit, neither at the molecular level nor at the cellular level (Arfi et al., 2011). Similar results have recently been observed with various antioxidant treatments in other LSD models, such as in the NPC1 mouse (Bascunan-Castillo et al., 2004; Smith et al., 2009). However, some caution is required in interpreting these data, as we tested only one time point looking at biochemical and molecular changes in brain, liver and spleen tissues. In the Sandhoff mouse, anti-oxidant therapy with vitamin $C$ did provide a modest but significant clinical improvement as a monotherapy (Jeyakumar et al., 2004). Future studies could be performed using more powerful anti-oxidant strategies with compounds that efficiently cross the blood-brain barrier (Agus et al., 1997). 


\section{Conclusions and perspectives}

After considerable in vitro and in vivo testing of a very large number of therapeutic candidates, a number of clinical trials are now in progress for many neuropathic lysosomal storage diseases. Clearly, one therapy approach will not, and indeed does not fit all disorders but the commonality of some pathology (e.g. neuroinflammation) and the general applicability of some strategies should encourage early stage similar studies to shorten the time between initial testing and human trials, if at all possible. Combination therapy strategies are supported by in vivo animal model data and are likely to be the way of the future. Well characterised animal models that are faithful to the human disorder they parallel are absolutely essential for timely and cogent progression through the research pipeline. Testing of therapies in animal models at various disease stages, i.e. pre and postsymptomatic in addition to late-stage disease, will enable to thoroughly understand the potential benefits and limitations of each therapeutic approach.

In parallel to the therapeutic research axis, the identification of new biomarkers is also crucial. Indeed, biomarkers are analytical tools that reflect the presence of a given disease (diagnostic biomarker). Biomarkers may also have prognostic significance for disease outcome, and emphasis is placed on those quantitative biomarkers which correlate with the clinical manifestations of the disease that affect quality of life, risk of complications or survival (surrogate biomarkers). Surrogate biomarkers have a critical role in the pharmaceutical licensing process and the monitoring of disease after the introduction of approved treatments. Surrogate biomarkers have special significance in the monitoring of treatments for rare diseases, where the small number of patients and heterogeneous expression of their underlying pathology pose formidable difficulties for direct study and where costly treatment must be justified in terms of efficacy. Much work will be needed to discover putative biomarkers and develop them for clinical use. More work generally will be needed across the fields of medicine to understand lysosomal diseases and their critical consequences on patients' life and quality of life.

\section{References}

Agus D. B., Gambhir S. S., Pardridge W. M., et al. (1997) J Clin Invest 100, 2842-2848.

Arfi A, Zisling R, Richard E, Batista L, Poenaru L, Futerman AH, Caillaud C. (2006) J Neurochem. 96(6):1572-9.

Arfi, A., Richard, M., Gandolphe, C. and Scherman, D. (2010). J Inherit Metab Dis. 33: 61-67.

Arfi, A., Richard, M., Gandolphe, C., Bonnefont-Rousselot, D., Thérond, P. and Scherman, D. (2011). J Mol Gen Metab. 103:18-25.

Barth, M.L. Fensom, A. and Harris, A. (1993) Hum. Genet. 91, 73-77.

Barton NW, Furbish FS, Murray GJ, Garfield M, Brady RO. (1990) Proc Natl Acad Sci U S A. 87(5):1913-6.

Bascunan-Castillo E. C., Erickson R. P., Howison C. M., et al. (2004). J Appl Genet 45, 461467.

Beck M (2007) Hum Genet 121:1-22.

Begley DJ, Brightman MW. (2003) Prog Drug Res. 61:39-78.

Bembi B, Marchetti F, Guerci VI, Ciana G, Addobbati R, Grasso D, Barone R, Cariati R, Fernandez-Guillen L, Butters T, Pittis MG. (2006) Neurology. 66(2):278-80. 
Benedict J. W., Sommers C. A. and Pearce D. A. (2007) J Neurosci Res 85, 2882-2891.

Bernier V, Lagacé M, Bichet DG, Bouvier M. (2004)Trends Endocrinol Metab. 15(5):222-8.

Beutler, E. (1993) Proc. Natl. Acad. Sci. USA 90, 5384-5390.

Biffi A, De Palma M, Quattrini A, Del Carro U, Amadio S, Visigalli I, Sessa M, Fasano S, Brambilla R, Marchesini S, Bordignon C, Naldini L.(2004) J Clin Invest. 113(8):111829.

Bolaens JJ, Prasad VK, Tolar J et al. (2010) Pediatr Clin North Am 57:123-145.

Bolhuis, P.A., Ponne, N.J., Bikker, H., Baas, F. and Vianney de Jong, J.M.B. (1993) Biochim. Biophys. Acta 1182, 142-146.

Brady RO, Barton NW, Grabowski GA. (1993) Arch Neurol. 50(11):1212-24.

Brady RO. (1966) N Engl J Med. 275(6):312-8.

Brady, R.O., Kanfer, J.N. and Shapiro, D. (1965) Biochem. Biophys. Res. Commun. 18, 221225.

Brightman MW, Reese TS. (1969) J Cell Biol. 40(3):648-77.

Brooks AI, Stein CS, Hughes SM, Heth J, McCray PM Jr, Sauter SL, Johnston JC, CorySlechta DA, Federoff HJ, Davidson BL. (2002) Proc Natl Acad Sci U S A. 99(9):621621.

Brown, C.A., Mclnnes, B., de Kremer, R.D. and Mahuran, D.J. (1992) Biochim. Biophys. Acta 1180, 91-98.

Bunge, S., Steglich, C., Beck, M., Rosenkranz, W., Schwinger, E., Hopwood, J.J. and Gal, A. (1992) Hum. Mol. Genet. 5, 335-339.

Butler D. and Bahr B. A. (2006) Antioxid Redox Signal 8, 185-196.

Cao Z, Petroulakis E, Salo T, Triggs-Raine B. (1997) J Biol Chem. 272(23):14975-82.

Chen, Y.Q., Raft, M.A., deGala, G. and Wenger, D.A. (1993) Hum. Mol. Genet. 2, 1841-1845.

Ciron C, Desmaris N, Colle MA, Raoul S, Joussemet B, Vérot L, Ausseil J, Froissart R, Roux F, Chérel Y, Ferry N, Lajat Y, Schwartz B, Vanier MT, Maire I, Tardieu M, Moullier P, Heard JM. (2006) Ann Neurol. 60(2):204-13.

Cleary M. A. and Wraith J. E. (1993) Arch Dis Child 69, 403-406.

Conzelmann, E. and Sandhoff, K. (1979) Hoppe Seyler Zeitschr Physiol. Chem. 360, 18371849.

Cox T, Lachmann R, Hollak C, Aerts J, van Weely S, Hrebícek M, Platt F, Butters T, Dwek R, Moyses C, Gow I, Elstein D, Zimran A. (2000) Lancet. 355(9214):1481-5.

Cox TM, Aerts JM, Andria G, Beck M, Belmatoug N, Bembi B, Chertkoff R, Vom Dahl S, Elstein D, Erikson A, Giralt M, Heitner R, Hollak C, Hrebicek M, Lewis S, Mehta A, Pastores GM, Rolfs A, Miranda MC, Zimran A. (2003) J Inherit Metab Dis. 26(6):513-26.

Dahl, N., LagerstriAm, M., Erikson, A. and Petterson, U. (1990) Am. J. Hum. Genet. 47, 275278.

De Duve C. (1964) J Theor Biol. 6(1):33-59.

De Palma M, Montini E, Santoni de Sio FR, Benedicenti F, Gentile A, Medico E, Naldini L. (2005) Blood. 105(6):2307-15.

Desmaris N, Verot L, Puech JP, Caillaud C, Vanier MT, Heard JM. (2004) Ann Neurol. 56(1):68-76.

Di Domenico C, Villani GR, Di Napoli D, Nusco E, Calì G, Nitsch L, Di Natale P. (2009) Am J Med Genet A. 149A(6):1209-18. 
Di Domenico C, Villani GR, Di Napoli D, Reyero EG, Lombardo A, Naldini L, Di Natale P. (2005) Hum Gene Ther. 16(1):81-90.

Dickson P, McEntee M, Vogler C, Le S, Levy B, Peinovich M, Hanson S, Passage M, Kakkis E. (2007) Mol Genet Metab. 91(1):61-8.

Dubois, G., Harzer, K. and Baumann, N. (1977) Am. J. Hum. Genet. 29, 191-194.

Dvorak-Ewell M, Wendt D, Hague C, Christianson T, Koppaka V, Crippen D, Kakkis E, Vellard M. (2010) PLoS One. 5(8):e12194.

Ellinwood NM, Ausseil J, Desmaris N, Bigou S, Liu S, Jens JK, Snella EM, Mohammed EE, Thomson CB, Raoul S, Joussemet B, Roux F, Chérel Y, Lajat Y, Piraud M, Benchaouir R, Hermening S, Petry H, Froissart R, Tardieu M, Ciron C, Moullier P, Parkes J, Kline KL, Maire I, Vanier MT, Heard JM, Colle MA. (2011) Mol Ther. 19(2):251-9.

Elstein D, Hollak C, Aerts JM, van Weely S, Maas M, Cox TM, Lachmann RH, Hrebicek M, Platt FM, Butters TD, Dwek RA, Zimran A. (2004) J Inherit Metab Dis. 27(6):757-66.

Feldhammer M, Durand S, Pshezhetsky AV. (2009) PLoS One. 4(10):e7434.

Ficko-Blean E, Stubbs KA, Nemirovsky O, Vocadlo DJ, Boraston AB. (2008) Proc Natl Acad Sci U S A. 105(18):6560-5.

Follenzi A, Battaglia M, Lombardo A, Annoni A, Roncarolo MG, Naldini L. (2004) Blood. 103(10):3700-9.

Fraldi A, Hemsley K, Crawley A, Lombardi A, Lau A, Sutherland L, Auricchio A, Ballabio A, Hopwood JJ. (2007) Hum Mol Genet. 16(22):2693-702.

Friso, A., Tomanin, R., Salvalaio, M. and Scarpa, M. (2010). British Journal of Pharmacology. 159: 1082-1091.

Fu H, DiRosario J, Kang L, Muenzer J, McCarty DM. (2010) J Gene Med.12(7):624-33.

Galanaud D, Tourbah A, Lehericy S, et al. (2009) Mol. Genet. Metab. 96(2):55-58.

German D. C., Liang C. L., Song T., et al. (2002) Neuroscience 109, 437-450.

Ginzburg L, Kacher Y, Futerman AH. (2004) Semin Cell Dev Biol. 15(4):417-31.

Giulian D., Young D. G., Woodward J., et al. (1988) J Neurosci 8, 709-714.

Grabowski, G.A. (1993) in: Advances in Human Genetics (Harris, H. and Hirschhorn, K., eds.), Vol. 21, pp. 377-341, Plenum press, New York.

Hacein-Bey-Abina S, von Kalle C, Schmidt M, Le Deist F, Wulffraat N, McIntyre E, Radford I, Villeval JL, Fraser CC, Cavazzana-Calvo M, Fischer A. (2003) N Engl J Med. 348(3):255-6.

Harmatz P, Giugliani R, Schwartz I, Guffon N, Teles EL, Miranda MC, Wraith JE, Beck M, Arash L, Scarpa M, Yu ZF, Wittes J, Berger KI, Newman MS, Lowe AM, Kakkis E, Swiedler SJ. (2006) J Pediatr. 148(4):533-539.

Hechtman, P., Kaplan, F., Bayleran, J., Boulay, B., Andermann, E., de Braekeleer, M., Melancon, S., Lambert, M., Potier, M., Gagne, R., Kolodny, E.H., Clow, C., Capua, A., Prevost, C. and Scriver, C. (1990) Am. J. Hum. Genet. 47, 815-822.

Heitner R, Elstein D, Aerts J, Weely S, Zimran A. (2002) Blood Cells Mol Dis. 28(2):127-33. Erratum in: Blood Cells Mol Dis. 2003 28(2):301.

Heldermon CD, Ohlemiller KK, Herzog ED, Vogler C, Qin E, Wozniak DF, Tan Y, Orrock JL, Sands MS. (2010) Mol Ther. 18(5):873-80.

Hemsley KM, Beard H, King BM, Hopwood JJ. (2008) Genes Brain Behav. [Epub ahead of print]

Hemsley KM, King B, Hopwood JJ. (2007) Mol Genet Metab. 90(3):313-28. 
Hemsley KM, Norman EJ, Crawley AC, Auclair D, King B, Fuller M, Lang DL, Dean CJ, Jolly RD, Hopwood JJ. (2009) Mol Genet Metab. 98(4):383-92.

Hess B, Saftig P, Hartmann D, Coenen R, Lüllmann-Rauch R, Goebel HH, Evers M, von Figura K, D'Hooge R, Nagels G, De Deyn P, Peters C, Gieselmann V. (1996) Proc Natl Acad Sci U S A. 93(25):14821-6.

Hohenschutz, C., Eich, P., Friedl, W., Waheed, A., Conzelmann, E. and Propping, P. (1989) Hum. Genet. 82, 45-48.

Hollak CE, Evers L, Aerts JM, van Oers MH. (1997) Blood Cells Mol Dis. 23(2):201-12.

Horowitz, M., Tsuri, G., Eyal, N., Berebi, A., Kolodny, E.H., Brady, R.O., Barton, N.W., Abrahamov, A. and Zimran, A. (1993) Am. J. Hum. Genet. 53, 921-930.

Horowitz, M., Wilder, S., Horowitz, Z., Reiner, O., Gelbart, T. and Beutler, E. (1989) Genomics 4, 87-96.

Jakobkiewicz-Banecka, J., Piotrowska, E., Narajczyk, M., Baranska, S. and Wegrzyn, G. (2009) J Biomed Sci. 16:26.

Jeyakumar M, Butters TD, Cortina-Borja M, Hunnam V, Proia RL, Perry VH, Dwek RA, Platt FM.(1999) Proc Natl Acad Sci U S A. 96(11):6388-93.

Jeyakumar M., Smith D. A., Williams I. M., et al. (2004) Ann Neurol 56, 642-649.

Jeyakumar M., Thomas R., Elliot-Smith E., et al. (2003) Brain 126, 974-987.

Kacem K, Lacombe P, Seylaz J, Bonvento G. (1998) Glia. 23(1):1-10.

Kakkis E, McEntee M, Vogler C, Le S, Levy B, Belichenko P, Mobley W, Dickson P, Hanson S, Passage M. (2004) Mol Genet Metab 83(1-2):163-74.

Kakkis ED, Schuchman E, He X, Wan Q, Kania S, Wiemelt S, Hasson CW, O'Malley T, Weil MA, Aguirre GA, Brown DE, Haskins ME. (2001) Mol Genet Metab. 72(3):199-208.

Klima, H., Tanaka, A., Schnabel, D., Nakano, T., SchriSder, M., Suzuki, K. and Sandhoff, K. (1991) FEBS Lett. 289, 260-264.

Kloska A, Jakóbkiewicz-Banecka J, Narajczyk M, Banecka-Majkutewicz Z, Węgrzyn G. (2011) Metab Brain Dis. 26(1):1-8.

Kniesel U, Wolburg H. (2000) Cell Mol Neurobiol. 20(1):57-76.

Kolodny, E.H., (1989) in: The Metabolic Basis of Inherited Disease (Scriver, C.R., Beaudet, A.L., Sly, W.S. and Valle, D., eds.), 8th ed. pp. 1721-1750, McGraw Hill, New York.

Kreysing, J., Von Figura, K. and Gieselmann, V. (1990) Eur. J. Biochem. 191, 627-631.

Kytzia, H.J. and Sandhoff, K. (1985) J. Biol. Chem. 260, 7568- 7572.

Lachmann RH, te Vruchte D, Lloyd-Evans E, Reinkensmeier G, Sillence DJ, FernandezGuillen L, Dwek RA, Butters TD, Cox TM, Platt FM. (2004) Neurobiol Dis. 16(3):654-8.

Lacorazza HD, Flax JD, Snyder EY, Jendoubi M. (1996) Nat Med. 2(4):424-9.

Lattanzi A, Neri M, Maderna C, di Girolamo I, Martino S, Orlacchio A, Amendola M, Naldini L, Gritti A. ( 2010) Hum Mol Genet.19(11):2208-27.

Lee WC, Courtenay A, Troendle FJ, Stallings-Mann ML, Dickey CA, DeLucia MW, Dickson DW, Eckman CB. (2005) FASEB J. 19(11):1549-51.

Leinekugel, P., Michel, S., Conzelmann, E. and Sandhoff, K. (1992) Hum. Genet. 88, 513-523.

Li C, Ziegler RJ, Cherry M, Lukason M, Desnick RJ, Yew NS, Cheng SH. (2002) Mol Ther. 5(6):745-54.

Ling EA. (1977) J Anat. 123(Pt 3):637-48. 
Malinowska M, Wilkinson FL, Langford-Smith KJ, Langford-Smith A, Brown JR, Crawford BE, Vanier MT, Grynkiewicz G, Wynn RF, Wraith JE, Wegrzyn G, Bigger BW. (2010) PLoS One. 5(12):e14192.

Malinowska, M., Wilkinson, F.L., Bennett, W., Langford-Smith, K.J., O'Leary, H.A., Jakobkiewicz-Banecka, J., Wynn, R., Wraith, J.E., Wegrzyn, G. and Bigger, B.W. (2009) Mol Gen Metab. 98: 235-242.

Mango RL, Xu L, Sands MS, Vogler C, Seiler G, Schwarz T, Haskins ME, Ponder KP. (2004) Mol Genet Metab. 82(1):4-19.

Matzner U, Gieselmann V. (2005) Expert Opin Biol Ther. 5(1):55-65.

Matzner U, Lüllmann-Rauch R, Stroobants S, Andersson C, Weigelt C, Eistrup C, Fogh J, D'Hooge R, Gieselmann V. (2009) Mol Ther. 17(4):600-6.

McDowell, G.A., Mules, E.H., Fabacher, P., Shapira, E. and Blitzer, M.G. (1992) Am. J. Hum. Genet. 51, 1071-1077.

McIntyre C, Byers S, Anson DS. (2010) J Gene Med. 12(9):717-28.

McIntyre C, Derrick Roberts AL, Ranieri E, Clements PR, Byers S, Anson DS. (2008) Mol Genet Metab. 93(4):411-8.

Meier, E.M., Schwarzmann, G., Fiirst, W. and Sandhoff, K. (1991) J. Biol. Chem. 266, 18791887.

Miller, R.D., Hoffmann, J.W., Powell, P.P., Kyle, J.W., Shipley, J.M., Bachinsky, D.R. and Sly, W.S. (1990) Genomics 7, 280-283.

Minagar A., Shapshak P., Fujimura R., et al. (2002) J Neurol Sci 202, 13-23.

Morreau, H., Bonten, E., Zhou, X.Y. and D'Azzo, A. (1991) DNA Cell. Biol. 10, 495-504.

Muenzer J, Lamsa JC, Garcia A, Dacosta J, Garcia J, Treco DA. (2002) Acta Paediatr Suppl. 91(439):98-9.

Muenzer J, Wraith JE, Beck M, Giugliani R, Harmatz P, Eng CM, Vellodi A, Martin R, Ramaswami U, Gucsavas-Calikoglu M, Vijayaraghavan S, Wendt S, Puga AC, Ulbrich B, Shinawi M, Cleary M, Piper D, Conway AM, Kimura A. (2006) Genet Med. 8(8):465-73. Erratum in: Genet Med. 2006 Sep;8(9):599.

Myerowitz R, Lawson D, Mizukami H, Mi Y, Tifft CJ, Proia RL. (2002) Hum Mol Genet. 11(11):1343-50.

Myerowitz, R. and Hogikyan, N.D. (1987) J. Biol. Chem. 262, 15396-15399.

Naito M, Nagai H, Kawano S, Umezu H, Zhu H, Moriyama H, Yamamoto T, Takatsuka H, Takei Y. (1996) J Leukoc Biol. 60(3):337-44.

Neote, K., Bapat, B., Dumbrille-Ross, A., Troxel, S.C., Schuster, S.M., Mahuran, D.J. and Gravel, R.A. (1988) Genomics 3, 279- 286.

Neote, K., Mclnnes, B., Mahuran, D.J. and Gravel, R.A. (1990) J. Clin. Invest. 86, 1524-1531.

Neufeld E. F., Muenzer, J. (2001) in: The mucopolysaccharidosis, in The Metabolic and Molecular Bases of Inherited Disease (Scriver CR, Beaudet AL, Sly WS et al., eds.) McGraw-Hill, New York.

Norden, A.G.W., Tennant, L.L. and O'Brien, J.S. (1974) J. Biol. Chem. 249, 7969-7976.

O'Brien, J.S. (1989) in: The Metabolic Basis of Inherited Disease (Scriver, C.R., Beaudet, A.L., Sly, W.S., Valle, D., eds.), 8th ed., pp 1797-1806, McGraw Hill, New York.

O'Dowd, B., Quan, F., Willard, H., Lamhonwan, A.M., Korneluk, R., Lowden, J.A., Gravel, R.A. and Mahuran, D. (1985) Proc. Natl. Acad. Sci. USA 82, 1184-1188. 
Ohmi K., Greenberg D. S., Rajavel K. S., et al. (2003) Activated microglia in cortex of mouse models of mucopolysaccharidoses I and IIIB. Proc Natl Acad Sci U S A 100, $1902-$ 1907.

Orii KO, Grubb JH, Vogler C, Levy B, Tan Y, Markova K, Davidson BL, Mao Q, Orii T, Kondo N, Sly WS. (2005) Mol Ther. 12(2):345-52.

Orvisky E, Sidransky E, McKinney CE, Lamarca ME, Samimi R, Krasnewich D, Martin BM, Ginns EI. (2000) Pediatr Res. 48(2):233-7.

Oshima, A., Tsuji, A., Nagao, Y., Sakubara, H. and Suzuki, Y. (1988) Biochem. Biophys. Res. Commun. 157, 238-244.

Palmieri, G., Capra, V., Romano, G., d'Urso, M., Johnson, S., Schlessinger, D., Morris, C.P., Hopwood, J.J., di Natale, P., Gatti, R. and Ballabio, A. (1992) Genomics 12, 52-57.

Passini MA, Lee EB, Heuer GG, Wolfe JH. (2002) J Neurosci. 22(15):6437-46.

Pastores GM, Barnett NL. (2003) Expert Opin Investig Drugs. 12(2):273-81.

Pastores GM, Patel MJ, Firooznia H. (2000) Curr Rheumatol Rep. 2(2):175-80.

Patterson MC, Vecchio D, Jacklin E, et al. (2010) J. Child Neurol. 25(3):300-305.

Patterson MC, Vecchio D, Prady H, Abel L, Wraith JE. (2007) Lancet Neurol. 6(9):765-772.

Paw, B.H., Tieu, P.T., Kaback, M.M., Lim, J. and Neufeld, E.F. (1990) Am. J. Hum. Genet. 47, 698-705.

Pelled D, Shogomori H, Futerman AH. (2000) J Inherit Metab Dis. 23(2):175-84.

Piotrowska E, Jakóbkiewicz-Banecka J, Tylki-Szymańska A et al. (2008). Curr Ther Res Clin Exp. 69: 166-179.

Piotrowska, E., Jakobkiewicz-Banecka, J., Branska, S., Tylki-Szymanska, A., Czartoryska, B., Wegrzyn, A. and Wegrzyn, G. (2006). Eur J Hum Gen. 14: 846-852.

Piotrowska, E., Jakobkiewicz-Banecka, J., Maryniak, A., Tylki-Szymanska, A., Puk, E., Liberek, A., Wegrzyn, A., Czartoryska, B., Slominska-Wojewodzka, M. and Wegrzyn, G. (2011). Med Sci Monitor. 17: 196-202.

Polten, A., Fluharty, A.L., Fluharty, C.B., Kappler, J., Von Figura, K. and Gieselmann, V. (1991) New. Engl. J. Med. 324, 18-22.

Proia, L.R. (1988) Proc. Natl. Acad. Sci. USA 85, 1883-1887.

Quintern, L.E., Schuchman, E.H., Levran, O., Suchi, M., Ferlinz, K., Reinke, H., Sandhoff, K. and Desnick, R.J. (1991) J. Biol. Chem. 266, 8531-8539.

Radin NS. (1996) Glycoconj J. 13(2):153-7.

Reolon G. K., Reinke A., de Oliveira M. R., et al. (2009) Cell Mol Neurobiol 29, 443-448.

Richard M, Arfi A, Seguin J, Gandolphe C, Scherman D. (2009) Gene Ther. 16(6):746-56.

Richard M., Arfi A., Rhinn H., et al. (2008) J Neurosci Res 86, 3285-3294.

Rozaklis T, Beard H, Hassiotis S, Garcia AR, Tonini M, Luck A, Pan J, Lamsa JC, Hopwood JJ, Hemsley KM. (2011) Exp Neurol. 230(1):123-30.

Sakai, N. (1994) Biochem. Biophys. Res. Commun. 198, 485-491.

Sandhoff, K., Conzelmann, E., Neufeld, E.F., Kaback, M.M. and Suzuki, K. (1989) in: The Metabolic Basis of Inherited Disease (Scriver, C.R., Beaudet, A.L., Sly, W.S. and Valle, D., eds.), 8th ed., pp. 1807-1839, McCaaw Hill, New York.

Sands MS, Davidson BL. (2006) Mol Ther. 13(5):839-49.

Sato H, Miyata M, Kasukawa R.(1996) J Rheumatol. 23(12):2027-32.

Sawkar AR, Cheng WC, Beutler E, Wong CH, Balch WE, Kelly JW. (2002) Proc Natl Acad Sci U S A. 99(24):15428-33.

Schuchman, E.H., Levran, O., Pereira, L.V. and Desnick, R.J. (1992) Genomics 12, 197-205. 
Scott, H.S., Anson, D.S., Orsborn, A.M., Nelson, P.V., Clements, P.R., Morris, C.P. and Hopwood, J.J. (1991) Proc. Natl. Acad. Sci. USA 88, 9695-9699.

Scott, H.S., Guo, X.H., Hopwood, J.J. and Morris, C.P. (1992) Genomics 13, 1311-1313.

Séguin R, Biernacki K, Rotondo RL, Prat A, Antel JP.(2003) J Neuropathol Exp Neurol. 62(4):412-9.

Settembre C., Fraldi A., Jahreiss L., et al. (2008) Hum Mol Genet 17, 119-129.

Simonaro C.M., D'Angelo M., Haskins M.E., Schuchman E.H. (2005) Pediatric Res. 57:701707.

Smith D., Wallom K. L., Williams I. M., et al. (2009) Neurobiol Dis 36, 242-251.

Snyder EY, Taylor RM, Wolfe JH. (1995) Nature. 374(6520):367-70.

Sorge, J., West, C., Westwood, B. and Beutler, E. (1985) Proc. Natl. Acad. Sci. USA 82, 72897293.

Souweidane MM, Fraser JF, Arkin LM, Sondhi D, Hackett NR, Kaminsky SM, Heier L, Kosofsky BE, Worgall S, Crystal RG, Kaplitt MG.(2010) J Neurosurg Pediatr. 6(2):115-22.

Spence, M.W. and Callahan, J.W. (1989) in: The Metabolic Basis of Inherited Disease (Scriver, C.R., Beaudet, A.L., Sly, W.S., Valle, D., eds.), 8th ed., pp. 1655-1676, McGraw Hill, New York.

Suzuki, K. and Suzuki, Y. (1989) in: The Metabolic Basis of Inherited Disease (Scriver, C.R., Beaudet, A.L., Sly, W.S. and Valle, D., eds.), pp. 1699-1720, 8th ed. McGraw Hill, New York.

Tamaki SJ, Jacobs Y, Dohse M et al. (2009) Cell Stem Cell 5:310-319

Taylor RM, Wolfe JH. (1997) Nat Med. 3(7):771-4.

Tomatsu S, Montaño AM, Dung VC, Grubb JH, Sly WS. (2009) Hum Mutat. 30(4):511-9.

Tomatsu S, Montaño AM, Ohashi A, Gutierrez MA, Oikawa H, Oguma T, Dung VC, Nishioka T, Orii T, Sly WS. (2008) Hum Mol Genet. 17(6):815-24. Epub 2007 Dec 3

Tropak MB, Reid SP, Guiral M, Withers SG, Mahuran D.(2004) J Biol Chem. 279(14):1347887.

Tsai, T.H. (2005) J Chromato A. 1073: 317-322.

Tsay, G.C. and Dawson, G. (1973) Biochem. Biophys. Res. Commun. 52, 759-773.

Tsuji D., Kuroki A., Ishibashi Y., et al. (2005) J Neurochem 92, 1497-1507.

US Food and Drug Administration. (2003) FDA approves first treatment for genetic metabolic disorder including Hurler disorder. Rockville, MD; 2003 Apr 30. FDA Talk Paper. No. T03-32.

Valenzano KJ, Khanna R, Powe AC, Boyd R, Lee G, Flanagan JJ, Benjamin ER. (2011) Assay Drug Dev Technol. 9(3):213-35.

van Furth R, Cohn ZA, Hirsch JG, Humphrey JH, Spector WG, Langevoort HL. (1972) Bull World Health Organ. 46(6):845-52.

Villani G. R., Gargiulo N., Faraonio R., et al. (2007) J Neurosci Res 85, 612-622.

Vogler C, Levy B, Grubb JH, Galvin N, Tan Y, Kakkis E, Pavloff N, Sly WS. (2005) Proc Natl Acad Sci U S A. 102(41):14777-82.

Wada R., Tifft C. J. and Proia R. L. (2000) Proc Natl Acad Sci U S A 97, 10954-10959.

Wang C. X. and Shuaib A. (2002) Prog Neurobiol 67, 161-172.

Williams, M.A. and Fukuda, M. (1990) J. Cell. Biol. 111, 955-966.

Wilson, P.J., Meany, C.A., Hopwood, J.J. and Morris, C.P. (1993) Genomics 17, 773-775. 
Wilson, P.J., Morris, C.P., Anson, D.S., Occhiodoro, T., Bielicki, J., Clements, P.R. and Hopwood, J.J. (1990) Proc. Natl. Acad. Sci. USA 87, 8531-8535.

Wilson, P.J., Suthers, G.K., Callen, D.F., Baker, E., Nelson, P.V., Cooper, A., Wraith, J.E., Sutherland, G.R., Morris, C.P. and Hopwood, J.J. (1991) Hum. Genet. 86, 505-508.

Wraith JE, Clarke LA, Beck M, Kolodny EH, Pastores GM, Muenzer J, Rapoport DM, Berger KI, Swiedler SJ, Kakkis ED, Braakman T, Chadbourne E, Walton-Bowen K, Cox GF. (2004) J Pediatr. 144(5):581-8.

Wraith JE, Imrie J. (2009) Ther. Clin. Risk Manag. 5:877-887.

Wu Y. P. and Proia R. L. (2004) Proc Natl Acad Sci U S A 101, 8425-8430.

Wu Y. P., Matsuda J., Kubota A., et al. (2000) J Neuropathol Exp Neurol 59, 628-639.

Wu, B.M. and Sly, W.S. (1993) Hum. Mutat. 2, 446-457.

Xia H, Mao Q, Davidson BL.(2001) Nat Biotechnol. 19(7):640-4.

Ying, N.M.K.Ng. and Wolfe L.S. (1975) Biochem. Biophys. Res. Commun. 66, 123-130.

Yogalingam G and Hopwood JJ. (2001) Hum Mutat 18(4):264-81

Zervas M, Somers KL, Thrall MA, Walkley SU. (2001) Curr Biol. 11(16):1283-7.

Zhao H, Bailey LA, Elsas LJ 2nd, Grinzaid KA, Grabowski GA. (2003) Am J Med Genet A. 116A(1):52-6.

Zheng Y, Rozengurt N, Ryazantsev S, Kohn DB, Satake N, Neufeld EF. (2003) Mol Genet Metab. 


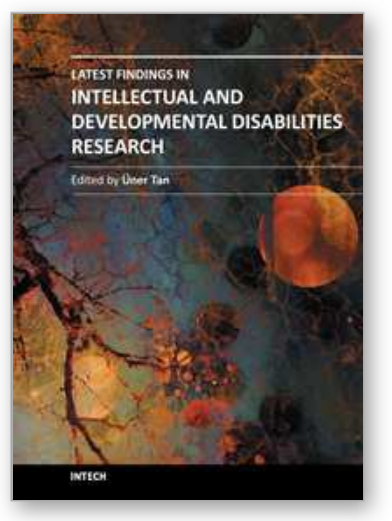

\author{
Latest Findings in Intellectual and Developmental Disabilities \\ Research \\ Edited by Prof. Uner Tan
}

ISBN 978-953-307-865-6

Hard cover, 404 pages

Publisher InTech

Published online 15, February, 2012

Published in print edition February, 2012

Intellectual and Developmental Disabilities presents reports on a wide range of areas in the field of neurological and intellectual disability, including habitual human quadrupedal locomotion with associated cognitive disabilities, Fragile $X$ syndrome, autism spectrum disorders, Down syndrome, and intellectual developmental disability among children in an African setting. Studies are presented from researchers around the world, looking at aspects as wide-ranging as the genetics behind the conditions to new and innovative therapeutic approaches.

\title{
How to reference
}

In order to correctly reference this scholarly work, feel free to copy and paste the following:

Audrey Arfi, Magali Richard and Daniel Scherman (2012). Innovative Therapeutic Approaches for Improving Patient Life Condition with a Neurological Lysosomal Disease, Latest Findings in Intellectual and Developmental Disabilities Research, Prof. Uner Tan (Ed.), ISBN: 978-953-307-865-6, InTech, Available from: http://www.intechopen.com/books/latest-findings-in-intellectual-and-developmental-disabilitiesresearch/innovative-therapeutic-approaches-for-improving-patient-life-condition-with-a-neurological-lysosomal

\section{INTECH}

open science | open minds

\section{InTech Europe}

University Campus STeP Ri Slavka Krautzeka 83/A 51000 Rijeka, Croatia Phone: +385 (51) 770447 Fax: +385 (51) 686166 www.intechopen.com

\section{InTech China}

Unit 405, Office Block, Hotel Equatorial Shanghai No.65, Yan An Road (West), Shanghai, 200040, China 中国上海市延安西路65号上海国际贵都大饭店办公楼 405 单元 Phone: +86-21-62489820

Fax: $+86-21-62489821$ 
(C) 2012 The Author(s). Licensee IntechOpen. This is an open access article distributed under the terms of the Creative Commons Attribution 3.0 License, which permits unrestricted use, distribution, and reproduction in any medium, provided the original work is properly cited. 